\title{
Biocontrol yeasts: mechanisms and applications
}

\author{
Florian M. Freimoser ${ }^{1}$ (D) Maria Paula Rueda-Mejia ${ }^{1} \cdot$ Bruno Tilocca $^{2,4} \cdot$ Quirico Migheli $^{2,3}$ (D)
}

Received: 17 July 2019 / Accepted: 17 September 2019 / Published online: 1 October 2019

(c) The Author(s) 2019

\begin{abstract}
Yeasts occur in all environments and have been described as potent antagonists of various plant pathogens. Due to their antagonistic ability, undemanding cultivation requirements, and limited biosafety concerns, many of these unicellular fungi have been considered for biocontrol applications. Here, we review the fundamental research on the mechanisms (e.g., competition, enzyme secretion, toxin production, volatiles, mycoparasitism, induction of resistance) by which biocontrol yeasts exert their activity as plant protection agents. In a second part, we focus on five yeast species (Candida oleophila, Aureobasidium pullulans, Metschnikowia fructicola, Cryptococcus albidus, Saccharomyces cerevisiae) that are or have been registered for the application as biocontrol products. These examples demonstrate the potential of yeasts for commercial biocontrol usage, but this review also highlights the scarcity of fundamental studies on yeast biocontrol mechanisms and of registered yeastbased biocontrol products. Yeast biocontrol mechanisms thus represent a largely unexplored field of research and plentiful opportunities for the development of commercial, yeast-based applications for plant protection exist.
\end{abstract}

Keywords Biological control $\cdot$ Microbial antagonism $\cdot$ Plant protection $\cdot$ Plant pathogens $\cdot$ Competition $\cdot$ Enzyme secretion $\cdot$ Toxin production $\cdot$ Volatiles $\cdot$ Mycoparasitism $\cdot$ Resistance induction

\section{Introduction}

Despite their relevance as model eukaryotes for biotechnological applications and in medical mycology, the potential use of antagonistic yeasts as biocontrol agents is still underexploited. Only a handful of yeast-based plant protection products has reached the market and even in fundamental research, antifungal yeasts have been neglected and poorly investigated with state-of-the-art technology and

Electronic supplementary material The online version of this article (https://doi.org/10.1007/s11274-019-2728-4) contains supplementary material, which is available to authorized users.

Florian M. Freimoser

florian.freimoser@agroscope.admin.ch

1 Agroscope, Research Division Plant Protection, Müller-Thurgau-Strasse 29, 8820 Wädenswil, Switzerland

2 Dipartimento di Agraria, Università degli Studi di Sassari, Viale Italia 39, 07100 Sassari, Italy

3 Istituto Nazionale di Biostrutture e Biosistemi and NRD Nucleo di Ricerca sulla Desertificazione, Università degli Studi di Sassari, Viale Italia 39, 07100 Sassari, Italy

4 Department of Health Sciences, University "Magna Græcia" of Catanzaro, Viale Europa, 88100 Catanzaro, Italy at the molecular level. Nevertheless, yeasts combine strong antifungal activities with advantageous properties for an application (e.g., strong antagonistic activity, culturability, formulatability, applicability, stress resistance) and are thereby promising for the development of biological plant protection agents. Furthermore, the close relatedness with model yeasts, particularly Saccharomyces cerevisiae, enables taking advantage of the molecular tools and plethora of data developed for these organisms for application-oriented and basic studies on biocontrol yeasts.

Biocontrol is mostly looked at and studied in a species/ isolate-centric manner: different species/isolates are tested against the target plant pathogen and the most active organism is studied with respect to its potential for biocontrol applications. However, for a successful application and improvement of biocontrol organisms, we first have to understand the biocontrol mechanisms involved and then confirm their expression under field conditions (Droby and Chalutz 1994; Spadaro and Droby 2016; Wisniewski et al. 2007). Here, different yeast biocontrol mechanisms are highlighted and a comprehensive overview on published work on antagonistic mechanisms of biocontrol yeasts is provided in Supplementary Table 1. 


\section{Advantageous yeast properties for potential biocontrol applications}

Any organism to be used as the active ingredient in a biocontrol product must be effective against its target disease, but secondary properties such as biosafety and registration issues, production requirements and conditions, formulation options, and the required application equipment are just as or even more important. Although the lack of invasive, filamentous growth of most yeasts may seem a disadvantage, the yeast-like morphology is the reason for wieldy culturability in fermentors, advantageous formulation characteristics and ample application options. As for bacteria, the single-celled morphology of yeasts also favours adhesion and biofilm formation, which directly influences environmental persistence, competitiveness and thereby improved biocontrol activity (Fanning and Mitchell 2012; Pandin et al. 2017; Rossouw et al. 2018; Verstrepen and Klis 2006).

While many $S$. cerevisiae strains contain the high-copy $2 \mu \mathrm{m}$ plasmid (i.e., 653 of 1011 sequenced $S$. cerevisiae strains) (Peter et al. 2018), most non-conventional yeasts lack plasmids (but can be engineered to maintain foreign, extra-chromosomal DNA by designing a plasmid vector containing intrinsic autonomously replicating and centromere sequences) (Cao et al. 2017). Yeasts thus share growth characteristics and biocontrol activities with bacteria without the risk of taking up or passing on plasmidbased antibiotic resistance, pathogenicity factors or toxin biosynthesis genes. In addition, horizontal gene transfer, albeit occurring more frequently in fungi than thought earlier, is significantly less frequent in yeasts, as compared to their prokaryotic counterparts, due to their more complex genome organisation (Fitzpatrick 2012; Moriguchi et al. 2013; Richards et al. 2011).

Yeasts have been used for food and beverage production for thousands of years, they are consumed directly as food supplements, and are widely employed in the food industry (Bekatorou et al. 2006; Querol and Fleet 2006). In many cases, these "food industry yeasts" belong to the same genus or even species as those intended for biocontrol (e.g., S. cerevisiae, Candida sake, Metschnikowia pulcherrima). This may be the reason why yeasts sensu lato are generally regarded as safe and therefore applying yeasts in crops and on food products elicits less concern than applications of bacteria or filamentous fungi (European Food Safety Authority 2005). Nonetheless, some yeasts, such as certain Candida or Cryptococcus species, are important fungal human pathogens (Butler et al. 2009; Miceli et al. 2011; Opulente et al. 2019). Properties such as dimorphism (e.g., the switch to an invasive growth form), growth at high temperatures (e.g., at or above $37{ }^{\circ} \mathrm{C}$ ) and resistance to fungicides are of particular concern and should be studied and assessed in detail before considering new isolates for biocontrol applications (Gauthier 2015, 2017; Robert et al. 2015).

\section{Mechanisms underlying the biocontrol activity of yeasts}

Understanding the mechanisms conferring biocontrol activity is the foundation for the informed and successful development and application of yeasts as plant protection agents (Droby and Chalutz 1994; Spadaro and Droby 2016; Wisniewski et al. 2007). For the biocontrol yeasts so far studied in detail, multiple mechanisms such as competition for nutrients and space, secretion of enzymes, toxin production, release of volatile organic compounds (VOCs), mycoparasitism and induction of resistance in plants are likely to be involved in the antagonistic function (Fig. 1) (Droby et al. 2009; Punja and Utkhede 2003; Wisniewski and Droby 2012). In most cases, the mechanisms outlined and discussed below have not been fully proven by molecular analyses (e.g., by gene deletion and complementation, heterologous expression), but rather proposed based on analogies with other biological systems. However, the increasing number of annotated yeast genomes and the availability of different transformation techniques should make it possible to decipher different mechanisms and to unambiguously confirm biocontrol mechanisms in future work.

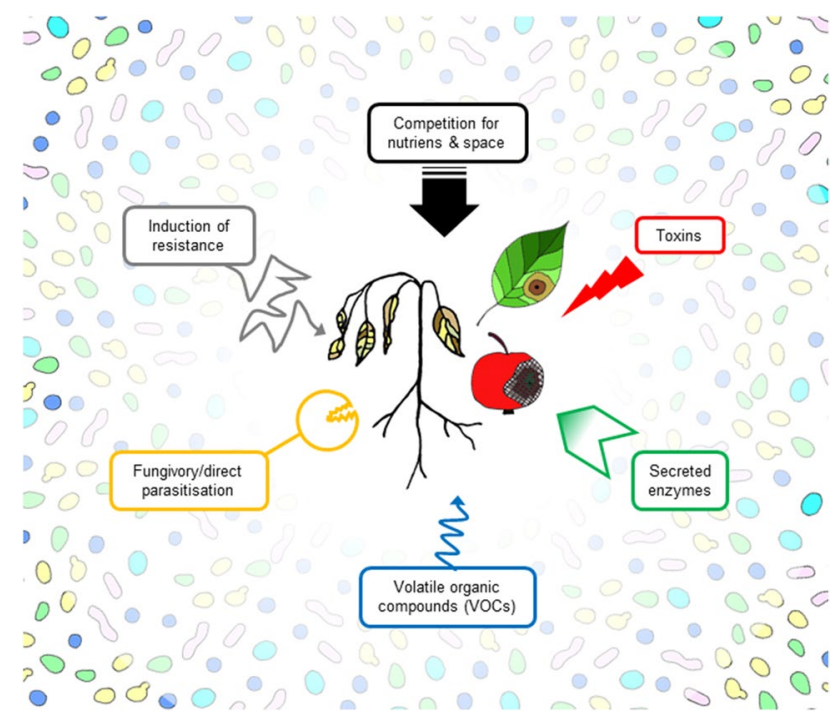

Fig. 1 Multiple mechanisms are involved in preventing plant diseases and conferring biocontrol activity to yeasts. The mechanisms studied and highlighted here are competition for nutrients and space, secretion of toxins, enzymes and volatile organic compounds, direct parasitisation (fungivory) and indirect mechanisms (i.e., induction of resistance) 


\section{Competition for nutrients and space}

All microorganisms compete with each other and their hosts for nutrients and space: this struggle is considered as the primary mode of action of biocontrol yeasts (Schaible and Kaufmann 2005; Spadaro and Droby 2016; Wisniewski et al. 2007). Competition is difficult to study mechanistically: it is likely more important in natural environments, where resources are limited and competitors plentiful. In community ecology, niche and nutrient competition have been intensely studied as determinants of species diversity. In nectar yeasts (e.g., Metschnikowia reukaufii), which are closely related to some biocontrol species, efficient resource depletion, due to the duplication of nitrogen transporter and metabolism genes, causes priority effects (i.e., order of species arrival determines community composition) and thus acts as a driver of competitiveness among different species (Dhami et al. 2016). With respect to competition for space, in vitro experiments performed on solid media seem to ascribe a minor role to a limitation in space. Although most yeasts grow well on agar plates, large differences in their antifungal activities were observed (Hilber-Bodmer et al. 2017). In addition, species-specific inhibition does not seem to occur, and a particular yeast is either strongly or weakly antagonistic against most fungi (Hilber-Bodmer et al. 2017). However, growing under field conditions activates diverse survival mechanisms and the competition for the physical niche might gain importance in such circumstances.

Most organisms and cells, from humans to bacteria, synthesise iron binding molecules to deprive competing organisms, pathogens or intracellular parasites of this essential element (Barber and Elde 2015; Johnson 2008). Also for biocontrol yeasts, iron is one of the most sought after nutrients and the competition for iron is recognised as an important mode of action (Spadaro and Droby 2016). In Aureobasidium pullulans, a siderophore identified as fusarinine $\mathrm{C}$ (fusigen) was identified and shown to exhibit antibacterial activity (Wang et al. 2009a, b). The peculiar red color of M. pulcherrima colonies is due to the formation of a cyclic dipeptide, pulcherriminic acid, that complexes iron (GoreLloyd et al. 2019). Pigmentless M. pulcherrima mutants were shown to exhibit reduced antifungal activity and iron deprivation of the fungal pathogen was suggested as one of several mechanisms by which this yeast antagonises plant pathogenic fungi (Gore-Lloyd et al. 2019; Sipiczki 2006). However, mutants lacking the ability to synthesise pulcherriminic acid still inhibited filamentous fungi strongly, suggesting that the antifungal activity was not only due to iron deprivation (Gore-Lloyd et al. 2019). The exact contribution of iron chelators to yeast biocontrol activity thus remains to be elucidated in detail.

Recently, it was shown that Saccharomycopsis schoenii lacks several components of the sulfur assimilation pathway and thus likely acquires methionine from its prey (Junker et al. 2019). Among yeasts, the inability to take up sulfur is specific to Saccharomycopsis, but some plant pathogenic fungi and Trichoderma species show a similar phenomenon, which may indicate that methionine is an important target for such organisms and highly competed over (Junker et al. 2019). Pioneering experiments aimed at evaluating the suitability of an easily transformable Pichia (Ogataea) angusta haploid strain to identify biocontrol-minus mutant clones: while the wild-type strain proved effective in reducing brown rot lesion caused by Monilinia fructicola on apple fruit, its derivate leucine-auxotrophic mutant L1 had no significant effect in controlling the pathogen. The addition of exogenous leucine fully restored the biocontrol capability of mutant L1, whereas a leucine stand-alone treatment showed no significant biocontrol effect (Fiori et al. 2008).

Biofilm formation may also be considered a specific and highly successful strategy to compete for space. Biofilms are microbial communities that live and grow on surfaces and can be comprised of a single species or represent multi-species consortia (Costa-Orlandi et al. 2017). Biofilms may exhibit vastly different properties as compared to free-floating cells and are considered a virulence factor for pathogenic microbes (Costa-Orlandi et al. 2017; Davey and O'Toole 2000; Desai et al. 2014). The development of a yeast biofilm starts with the adhesion of individual cells to a surface and usually involves cell wall modifications, secretion of an extracellular matrix, and often the formation of hyphae or pseudohyphae (Cavalheiro and Teixeira 2018; Costa-Orlandi et al. 2017). The process has been studied in detail and at the molecular level in medically relevant and model yeasts (Cabral et al. 2014; Cavalheiro and Teixeira 2018; d'Enfert and Janbon 2016; Lohse et al. 2018; Reynolds and Fink 2001). In biocontrol yeasts, biofilm formation, mainly in the phyllo- and carposphere (i.e., in wounds), is now considered an important mode of action and has been widely studied. However, the molecular underpinnings of the process and the composition of different biofilms (e.g., cell differentiation, multispecies biofilms) have only been studied in detail for Pichia fermentans. This species proved particularly intriguing in this respect, because biofilm formation in apple wounds protects against postharvest diseases, while on peaches $P$. fermentans switches from the yeastlike to the hyphal growth form and causes rapid decay of inoculated fruits in the absence of a plant pathogen (Fiori et al. 2012; Giobbe et al. 2007; Maserti et al. 2015; Sanna et al. 2012, 2013). Based on this "Jekyll \& Hyde" pathogenic behaviour of P. fermentans on peach fruit, the capability to differentiate hyphae and pseudohyphae under particular growth conditions (e.g., depending on the nitrogen source) has been proposed as a potential biohazard factor for biocontrol yeasts (Giobbe et al. 2007). Besides P. fermentans, biofilm formation has also been implicated in the protective 


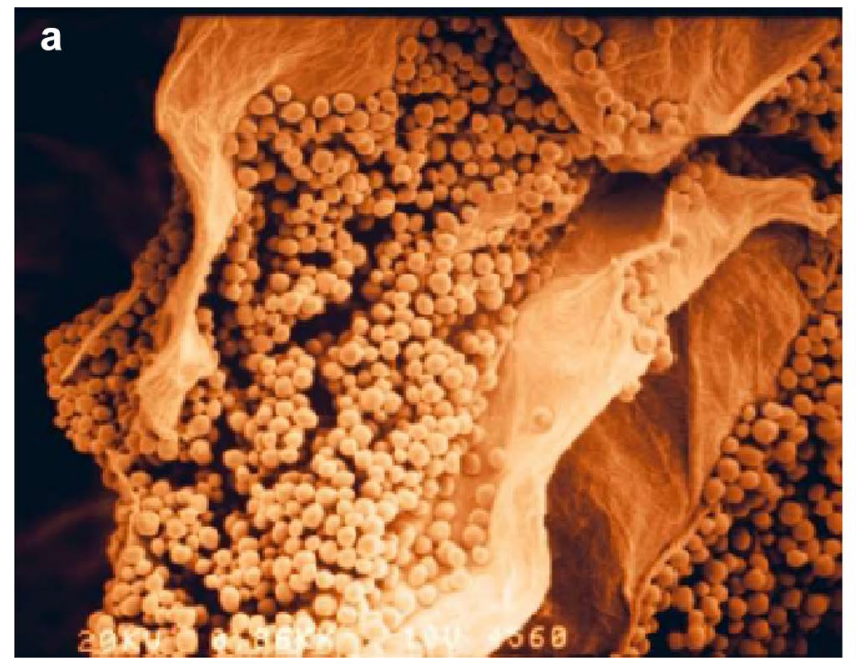

Fig. 2 Colonisation a of the inner surface of an apple wound by the Saccharomyces cerevisiae flor strain M25. b Penicillium expansum germ tubes grow onto the yeast cells, but contact with the apple tissue

and biocontrol activities of A. pullulans, Kloeckera apiculata, S. cerevisiae, Pichia kudriavzevii, W. anomalus, and M. pulcherrima (Supplementary Table 1) (Chi et al. 2015; Klein and Kupper 2018; Ortu et al. 2005; Pu et al. 2014; Wachowska et al. 2016). In a S. cerevisiae flor strain, biofilm cells were far more efficient than planktonic cells in colonising the inner surface of apple wounds, thereby controlling the development of blue mould caused by P. expansum (Ortu et al. 2005; Scherm et al. 2003) (Fig. 2).

\section{Secreted enzymes}

The secretion of enzymes degrading cellular components is a common feature in all kinds of host-pathogen interactions and has been intensively studied. Usually, such enzymes are upregulated in nutrient poor conditions and serve the provision of nutrients (e.g., carbon sources, amino acids) that are released from "prey" cells, which may lead to the killing of these cells (i.e., mycoparasitism/fungivory; see below). Secreted enzymes such as chitinases, glucanases, or proteases are thus regularly reported and highlighted in antagonistic yeasts and implicated in their biocontrol activity.

\section{Chitinases}

The secretion of chitinolytic enzymes is considered a desirable characteristic for biocontrol agents as it allows degrading fungal cell walls (Zajc et al. 2019). Chitin degrading activity has been measured in biocontrol yeasts of the genera Aureobasidium, Candida, Debaryomyces, Metschnikowia, Meyerozyma, Pichia, Saccharomyces, Tilletiopsis, and Wickerhamomyces and in Saccharomycopsis, chitinase expression

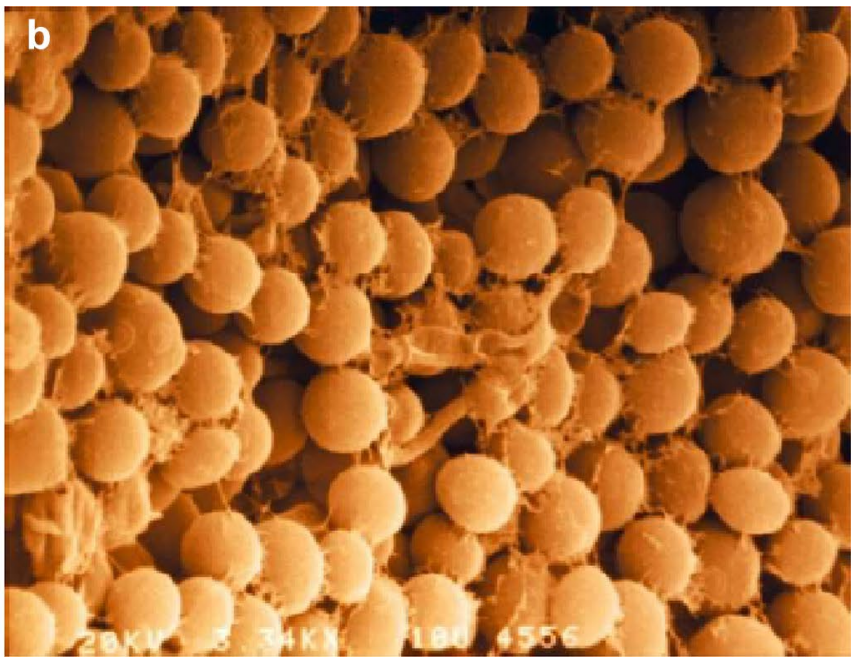

is prevented by a thick yeast cell layer. The presence of an extracellular matrix is likely to assure an effective protection of the apple tissue (Ortu et al. unpublished)

was detected in the presence of prey cells (Supplementary Table 1) (Bar-Shimon et al. 2004; Junker et al. 2019; Lopes et al. 2015; Pretscher et al. 2018; Saravanakumar et al. 2009; Urquhart and Punja 2002; Zajc et al. 2019; Zhang et al. 2011). So far, the corresponding chitinase-encoding genes have not been cloned, deleted or overexpressed to unequivocally link these enzymes to biocontrol activity. However, chitinases from other sources than yeasts (i.e., filamentous fungi and bacteria) have demonstrated biocontrol activity against plant pathogenic fungi and chitinases are widely studied as potential biopesticides, targets for resistance breeding, or as transgenes in genetically modified plants (Dahiya et al. 2006; Herrera-Estrella and Chet 1999; Nagpure et al. 2014). Chitinases likely also affect biocontrol activity indirectly, because chito-oligosaccharides (CHOS; the results of chitin degradation) are potent inducers of plant immune responses (Kombrink et al. 2011; Langner and Gohre 2015; Liu et al. 2012, 2014).

\section{Glucanases}

Glucans are major cell wall components in fungi and exoglucanases are involved in cell wall modification, cell adhesion, and killer toxin resistance (Adams 2004; Jiang et al. 1995; Tsai et al. 2011; Xu et al. 2013). A 1,3- $\beta$-glucanase (CoEXG1) from Candida oleophila was the first gene cloned in this organism (Segal et al. 2002). Initial overexpression or deletion analyses of $C o E X G 1$ did not significantly affect spore germination of Penicillium digitatum (Yehuda et al. 2003), but later studies documented reduced inhibitory activity of the $\beta$-exoglucanase deletion mutant as compared to the wild type and overexpressing strain (in vitro and in 
fructo), thereby proving the involvement of glucanases in yeast biocontrol activity (Bar-Shimon et al. 2004). In Wickerhamomyces anomalus (Pichia anomala), the deletion of the two exo- $\beta$-glucanases (PaEXG1 and PaEXG2) significantly reduced biocontrol activity on fruits against Botrytis cinerea (Friel et al. 2007), while the single deletion of PaEXG2 did not reduce biocontrol performance (Grevesse et al. 2003). At the transcriptional level, differential upregulation of two $W$. anomalus ( $P$. anomala) exoglucanase genes was shown during the interaction with plant pathogenic fungi on infected fruits or growth with fungal cell wall preparations (Parafati et al. 2017a). Exoglucanase activity has also been detected in numerous biocontrol yeasts (see Supplementary Table 1) (Chan and Tian 2005) and was linked to antagonistic activity, but without demonstrating a causal involvement. In Rhodotorula glutinis and Cryptococcus laurentii, $\beta$-1,3-glucanase activity did not correlate with the respective inhibitory activity against $B$. cinerea (Castoria et al. 1997). Six S. cerevisiae isolates exhibiting antifungal activity against Colletotrichum acutatum secreted exoglucanases, as did a Pichia guilliermondi biocontrol isolate (Lopes et al. 2015; Zhang et al. 2011).

\section{Lipases}

Lipolytic activity is frequently found when screening for extracellular enzymatic activity in yeast and yeast-like strains (Arroyo-Lopez et al. 2008; Buzzini and Martini 2002; Hernandez et al. 2007). This trait has been related to the consumption of previously accumulated lipids (in the so-called 'oleaginous' yeasts), and to cold tolerance in extremophilic yeasts (Białkowska and Turkiewicz 2014; Breuer and Harms 2006; Papanikolaou and Aggelis 2011; Szczęsna-Antczak et al. 2014). Besides this, lipase activity has been detected and shown to be involved in the pathogenicity of yeasts such as Candida, Cryptococcus, or Malassezia species (Mayer et al. 2013; Park et al. 2013; Sommer et al. 2016). Since a number of studies have highlighted the role of lipases in the biocontrol efficacy of bacteria and fungi against plant diseases and pests (Ali et al. 2009; Berto et al. 2001; Beys da Silva et al. 2010a, b; Keyhani 2018; Manuel et al. 2012; Sánchez-Pérez et al. 2014; Vial et al. 2007; Zha et al. 2014), the lipolytic activity of antagonistic yeasts may represent a promising target for innovative studies on biological control applications.

\section{Proteases}

Although proteases are important virulence factors in entomopathogenic fungi and filamentous mycoparasites, they have been scarcely studied in biocontrol yeasts (Supplementary Table 1). Since protease activity was only detected at later growth stages (after 6-8 days of growth in nutrient rich medium) in C. oleophila cultures, a minor function in biocontrol activity was hypothesised (Bar-Shimon et al. 2004). In contrast, the alkaline serine protease Alp5 from $A$. pullulans reduced spore germination and germ tube length of Penicillium expansum, B. cinerea, $M$. fructicola and Alternaria alternata in vitro and exhibited a concentration-dependent inhibitory effect on these pathogens on apple (Banani et al. 2014; Zhang et al. 2012). Protease activity has also been reported in the genera Metschnikowia, Pichia, and Wickerhamomyces, but not further studied or confirmed (Pretscher et al. 2018). Finally, Saccharomycopsis protease (and also glucanase) transcripts were significantly enriched during predation, but neither functionally investigated (Junker et al. 2019).

\section{Toxin production}

Yeasts are not known as prolific producers of secondary metabolites, which is one of the reasons why they often raise less biosafety concerns. Consequently, relatively few toxic molecules that may contribute to biocontrol activity have been described (Supplementary Table 1). Flocculosin is a low molecular weight cellobiose lipid produced by the biocontrol yeast Pseudozyma flocculosa (Mimee et al. 2005, 2009; Teichmann et al. 2011). A. pullulans (introduced in more detail below) produces diverse polymers (e.g., pullulan, aubasidan-like exopolysaccharide, $\operatorname{poly}(\beta$-L-malic acid)), lipids, volatiles, enzymes, and secondary metabolites. Some of these metabolites (e.g., aureobasidins, liamocins, 2-propylacrylic acid, 2-methylenesuccinic acid) confer antagonistic activity against bacteria or fungi (Prasongsuk et al. 2018; Price et al. 2013, 2017; Takesako et al. 1991; Zain et al. 2009). Toxin production provided a competitive advantage to $A$. pullulans under dry, oligotrophic conditions, whereas it had no effect (as compared to yeasts not producing toxins) on antagonistic activity in more humid environments (McCormack et al. 1995). The most prominent toxins produced by many biocontrol yeast strains are proteinaceous killer toxins (Supplementary Table 1) (Bajaj et al. 2013; Banjara et al. 2016; Belda et al. 2017; Buzdar et al. 2011; Buzzini et al. 2004; Chen et al. 2000; Coelho et al. 2009; Comitini and Ciani 2011; Comitini et al. 2004; da Silva et al. 2008; De Ingeniis et al. 2009; Golubev et al. 2006; Guo et al. 2013; Guyard et al. 2002a, b; Hua et al. 2010; Kasahara 1994a, b; Klassen et al. 2004; Marquina et al. 2001; Ramirez et al. 2015; Rodriguez-Cousino et al. 2011; Santos and Marquina 2004a, b; Santos et al. 2002, 2009; Suzuki and Nikkuni 1994; Vepstaite-Monstavice et al. 2018; Wang et al. 2007, 2012a; Weiler and Schmitt 2003). These proteins were originally identified in $S$. cerevisiae and seem to mainly kill competing yeast species (Luksa et al. 2015; Schmitt and Breinig 2006). Yeast killer toxins have thus been mainly studied with respect to the control of spoilage yeasts in 
the beverage and food industry or for medical applications (Chessa et al. 2017; Chi et al. 2010; Lowes et al. 2000; Mannazzu et al. 2019; Schmitt and Breinig 2002). However, several of these toxins also inhibit or kill plant pathogenic fungi and were thus proposed for plant protection (Corbaci and Ucar 2018; Liu et al. 2015; Marquina et al. 2002; Perez et al. 2016). Nevertheless, further investigations to evaluate the specificity of yeast toxins and assess their effects on other beneficial microorganisms (e.g., in the phyllosphere, in soil microbiota and, in the case of edible commodities, the human gut) are required, particularly in the light of a possible registration.

\section{Volatile organic compounds}

Volatile organic compounds (VOCs) are small (usually $<300 \mathrm{Da})$ molecules with low water solubility and high vapour pressure. VOCs include a panoply of molecular classes, including hydrocarbons, alcohols, thioalcohols, aldehydes, ketones, thioesters, cyclohexanes, heterocyclic compounds, phenols and benzene derivatives (Morath et al. 2012). The chemical composition of each blend of volatiles (the so-called volatilome) may change depending on the producing yeast, the antagonised pathogen and the ecological niche where the cross-talking species are growing (Parafati et al. 2017b). Recent experimental evidence has revealed the key role of the yeast volatilome in yeastpathogen interactions, including postharvest pathogens, and mycotoxin-producing fungi (Supplementary Table 1) (Bruce et al. 2003; Lemos Jr 2016; Parafati et al. 2015). Volatiles produced by $A$. pullulans proved efficient in reducing the growth and infection by $B$. cinerea, $C$. acutatum, $P$. expansum, $P$. digitatum and $P$. italicum both in vitro and in planta (Di Francesco et al. 2014). The biocontrol activity of different food yeasts such as $W$. anomalus, $M$. pulcherrima, $S$. cerevisiae and $A$. pullulans against $B$. cinerea in vitro and on table grape berries was largely attributed to the production of VOCs (Parafati et al. 2015). Similarly, VOCs released by $C$. sake reduced the incidence of apple rot caused by $P$. expansum and B. cinerea (Arrarte et al. 2017). The inhibitory activity of Sporidiobolus pararoseus on spore germination and mycelial growth of $B$. cinerea was mainly attributed to 2-ethyl-1-hexanol (Huang et al. 2012), whereas Candida intermedia produced 1,3,5,7-cyclooctatetraene, 3-methyl1-butanol, 2-nonanone, and phenylethyl alcohol as the major components of its volatilome during the interaction with this pathogen (Huang et al. 2011). VOCs released by P. anomala, Pichia kluyveri, and Hanseniaspora uvarum inhibited Aspergillus ochraceus growth and ochratoxin A production during processing of coffee (Masoud et al. 2005), and 2-phenylethanol was identified as the key component of the P. anomala volatilome preventing spore germination, mycelial growth and toxin production by Aspergillus flavus
(Hua et al. 2014). More than twenty different VOCs were identified in the volatilomes of selected biocontrol strains of Cyberlindnera jadinii, Candida friedrichii, C. intermedia, and Lachancea thermotolerans, but 2-phenylethanol was the most abundant and responsible for the inhibition of both mycelial growth and ochratoxin A production by Aspergillus carbonarius and A. ochraceus (Farbo et al. 2018; Fiori et al. 2014; Tilocca et al. 2019).

\section{Mycoparasitism}

Mycoparasitism (or fungivory, i.e., the consumption of one fungus by another) is rarely described and poorly studied in yeasts. $P$. guilliermondii was shown to strongly adhere to hyphae of the plant pathogen $B$. cinerea and to cause hyphal collapse, presumably due to the secretion of hydrolytic enzymes such as glucanases (see above) (Wisniewski et al. 1991). Similarly, the yeast-like Ustilaginomycete Pseudozyma aphidis parasitises the powdery mildew pathogen Podosphaera xanthii and B. cinerea (Calderon et al. 2019; Gafni et al. 2015). The genus Saccharomycopsis, comprising predacious yeasts directly feeding on their prey, was studied with respect to biocontrol of different Penicillium species as well as clinically relevant yeasts (Junker et al. 2017, 2018, 2019; Lachance and Pang 1997; Pimenta et al. 2008).

\section{Induction of resistance}

Plants feature an innate immune system that recognises and responds to the presence of microorganisms (Chisholm et al. 2006; Jones and Dangl 2006). This plant immune response can induce resistance systemically and is the basis for the application of microorganisms as plant fertilisers and fortifiers (Gozzo and Faoro 2013; Pieterse et al. 2014). Biocontrol yeasts can elicit systemic resistance of plants against a broad range of pathogens (Supplementary Table 1) (Barda et al. 2015; Buxdorf et al. 2013a, b; Lee et al. 2017; Liu et al. 2016) and this activity is suggested to contribute to their biocontrol activity. For example, S. cerevisiae, Rhodosporidium paludigenum, Candida saitoana, $C$. oleophila and Metschnikowia species induce an innate immune response and eventually cause resistance against phyllosphere pathogens in fruits (De Miccolis Angelini et al. 2019; Droby et al. 2002; El Ghaouth et al. 2003; Hadwiger et al. 2015; Hershkovitz et al. 2012; Lu et al. 2013, 2014; Sun et al. 2018). In the case of $C$. oleophila, this induction has been attributed to the overproduction of reactive oxygen species in the plant (Macarisin et al. 2010), but yeast cell components (from dead cells) can also trigger systemic resistance (De Miccolis Angelini et al. 2019). Living cells are consequently not always required for such induction. In some cases, biocontrol yeasts such as $C$. laurentii, Cryptococcus flavescens, and $R$. glutinis have been used in combination with resistance 
inducers such as salicylic acid or rhamnolipids (Yan et al. 2014; Yu and Zheng 2006; Zhang et al. 2007c).

\section{Registered biocontrol yeast species}

There is a huge discrepancy between the plethora of "biocontrol yeasts" described in scientific publications and the few yeast-based plant protection products that are registered and marketed as plant protection products. A range of factors (e.g., lack of mechanistic understanding, hurdles/costs of registration, lack of partners/consortia with required expertise, little commercial potential) are likely responsible for this apparent difficulty to develop yeast-based plant protection products. Here, we briefly highlight five yeast species (C. oleophila, A. pullulans, M. fructicola, C. albidus, and S. cerevisiae) that are currently or have been registered as plant protection agents.

\section{Candida oleophila}

Species of the genus Candida are often isolated from environmental samples and many isolates strongly inhibit plant pathogens. Representatives are, for example, C. diversa ( $\mathrm{Li}$ et al. 2016; Liu et al. 2017), C. ernobii (Liu et al. 2010), $C$. guillermonidi (McLaughlin et al. 1992; Papon et al. 2013; Saligkarias et al. 2002), C. oleophila (Droby et al. 2002; Gamagae et al. 2003; Lahlali et al. 2004; Molinu et al. 2011; Wang et al. 2012b), C. saitoana (Arras et al. 2006, 2010; El-Ghaouth et al. 1998, 2000a, b, c), C. sake (Arrarte et al. 2017; Calvo-Garrido et al. 2013; Canamas et al. 2008; Carbo et al. 2018; McLaughlin et al. 1992; Morales et al. 2008; Nunes et al. 2002a, b; Torres et al. 2006; Usall et al. 2000; Yehuda et al. 2003), or C. subhashii (Hilber-Bodmer et al. 2017) that have all been envisioned as biocontrol agents against mold and postharvest diseases of pome, stone and citrus fruit. In particular for C. sake, a wealth of studies on production and formulation have been performed in order to render postharvest biocontrol more reliable and efficacious (Abadias et al. 2000, 2001a, b, c, 2003; Canamas et al. 2008; Carbo et al. 2018; Nunes et al. 2002a, b; Torres et al. 2003, 2006; Usall et al. 2000).

C. oleophila was the first yeast to be developed into a commercial plant protection agent and the fundamental research accompanying this initiative has established, for the first time, different mechanisms underlying the antifungal activity of yeasts in general. Although yeasts are generally believed to antagonise plant pathogenic fungi due to their competition for nutrients and space, the work on C. oleophila and other Candida species identified hydrolytic enzymes such as proteases, chitinases and glucanases, as well as volatile compounds, that have been implicated in antifungal activity (Bar-Shimon et al. 2004; Huang et al. 2011; Segal et al. 2002) (also see above and Supplementary Table 1). Furthermore, biofilm formation, high osmotolerance, induction of resistance in the plant/fruit, and direct parasitism of hyphae were shown to contribute to the biocontrol activity of Candida species (Droby and Chalutz 1994; Droby et al. 2002; El Ghaouth et al. 2003; Wisniewski et al. 1995, 2007). To overcome the inconsistent performance of the initial Candida-based biocontrol products (and of early biological plant protection products in general), combinations with fungicides, different buffers (e.g., calcium chloride, bicarbonate), chitosan, or lysozyme were studied (Droby et al. 1998, 2003a, b; El-Ghaouth and Wilson 2002; Scherm et al. 2003; Wilson and El-Ghaouth 2002). C. oleophila was also transformed, by electroporation and with the hygromycin $\mathrm{B}$ gene as a marker, to study its mode of antagonism at the molecular level (Yehuda et al. 2001).

The $C$. oleophila strains I-182 and O have been developed into the biocontrol products Aspire ${ }^{\circledR}$ and Nexy ${ }^{\circledR}$, respectively. The latter was the first biocontrol yeast to be registered against a postharvest disease (Wisniewski et al. 2007) and C. oleophila strain O has been approved as a plant protection agent in Europe in 2013 (European Commission Health \& Consumers Directorate-General 2013; European Food Safety Authority (EFSA) 2015a).

\section{Aureobasidium pullulans}

The saprophytic ascomycete A. pullulans is frequently isolated from leaf, flower or soil samples, occurs worldwide, and exhibits a polymorphic appearance. Biocontrol activity has been documented for several A. pullulans strains, but only DSM 14940 (CF 10) and DSM 14941 (CF 40) are registered, in mixture, as active ingredients of plant protection products against the fireblight disease caused by the bacterium Erwinia amylovora and postharvest diseases (European Food Safety Authority (EFSA) 2013). These two A. pullulans strains were selected based on their strong inhibition towards E. amylovora in co-culture experiments at high synthetic nectar concentration (25\%) (Seibold et al. 2004). The two isolates DSM 14940 (CF 10) and DSM 14941 (CF 40) also exhibited stronger inhibitory activity, in detached flower assays, than other bacterial and yeast antagonists (Kunz 2004). The two strains were formulated as a wettable powder under the product name Blossom-Protect ${ }^{\circledR}$ and tested under field conditions at different sites and over several years (Kunz 2004; Kunz and Haug 2006; Kunz et al. 2011; Seibold et al. 2004). The same two A. pullulans strains were also developed and registered to control postharvest diseases of apple as the product Boni-Protect ${ }^{\circledR}$ (Weiss and Mögel 2006). Similar applications against storage and rot diseases of strawberries, plum and sour cherries are being studied (Holb and Kunz 2013; Weiss et al. 2014). 
The two registered products containing A. pullulans as an active ingredient are interesting from different points of view. Contrary to the large majority of biocontrol products, Blossom- and Boni-Protect ${ }^{\circledR}$ contain two different strains, albeit belonging to the same species. As for many other biocontrol yeasts, the A. pullulans mode of action involves competition for space and nutrients, but enzymes such as proteases, chitinases or secreted molecules (see above) may also be involved. Specific metabolites or enzymes and their contribution to the biocontrol activity of DSM 14940 (CF 10) and DSM 14941 (CF 40) have not been identified and the strains do not seem to have been characterised genetically. In contrast to most registered plant protection products, including biological products, the original Blossom-Protect ${ }^{\circledR}$ has a rather limited range of application. The expansion to novel indications, beyond fireblight of pome fruit trees, is thus certainly also motivated by economic needs.

\section{Metschnikowia fructicola}

The genus Metschnikowia comprises species of mainly phyllosphere and nectar yeasts that are globally distributed (Chappell and Fukami 2018; Lachance et al. 2001; Pozo et al. 2012; Slavikova et al. 2007; Vadkertiova et al. 2012). Among those, M. fructicola and M. pulcherrima are the most studied with respect to biocontrol, are able to inhibit a range of postharvest and plant rot diseases, and include the most potent antagonistic yeasts that have ever been identified (Akgun Karabulut et al. 2003; Hilber-Bodmer et al. 2017; Parafati et al. 2015; Piano et al. 1997; Saravanakumar et al. 2008; Spadaro et al. 2010a, b; Turkel et al. 2014). Complete genomes are available for several Metschnikowia species, including $M$. fructicola and $M$. pulcherrima (Gore-Lloyd et al. 2019; Piombo et al. 2018), and transformation protocols have been established and used to express green fluorescent protein and complement a naturally occurring mutant (Gore-Lloyd et al. 2019; Nigro et al. 1999).

The strong antifungal activity of Metschnikowia species is mediated by a range of mechanisms that involve competition for nutrients (e.g.; amino acids, iron), secretion of glucanases and chitinases, and the production of volatile organic compounds (Banani et al. 2015; Dhami et al. 2016; Gore-Lloyd et al. 2019; Hershkovitz et al. 2013; Saravanakumar et al. 2008; Sipiczki 2006; Zajc et al. 2019). The application of Metschnikowia cells to fruits (e.g., grapefruit) also induces an oxidative burst in the plant tissue that eventually results in the activation of plant defense responses (Hershkovitz et al. 2012; Macarisin et al. 2010).

Originally, M. fructicola, isolate NRRL Y-30752, was isolated and discovered in Israel and developed and registered as a biocontrol product for preventing postharvest diseases, particularly in sweet potato and carrot (Eshel et al. 2009; Kurtzman and Droby 2001; Wisniewski and Droby
2012). M. fructicola has also been patented as an antagonist of plant pathogenic microorganisms (Droby and El-Gerberia 2006). It seems that over time different companies showed interest in developing a biological fungicide based on $M$. fructicola NRRL Y-30752, but the isolate is now pursued by Koppert Biological Systems and has recently been approved as a plant protection agent against fungal diseases in stone fruits, strawberries and grapes by the European Food Safety Authority (EFSA) (European Food Safety Authority (EFSA) 2015c, 2017).

\section{Cryptococcus albidus}

Basidiomycetes of the genus Cryptococcus are widespread in nature and frequently isolated from water sources, soil and decaying plant material. Studied for their potential to produce high lipid yields for biodiesel production, strains of C. albidus, C. laurentii and $C$. flavus have also been shown to protect peach, cherry, strawberry, tomato, citrus and pome fruits against postharvest decay (Elad et al. 1994; Tian et al. 2004; Zhang et al. 2007a, b). C. albidus was used as a biocontrol agent in the product Yieldplus ${ }^{\circledR}$, which was registered in 1997 and marketed by Anchor Bio-Technologies in South Africa. This product was sold for over 15 years, but it has now been withdrawn from the market (Mbili 2012). Yieldplus ${ }^{\circledR}$ was formulated for pome and citrus fruits against $B$. cinerea and P. expansum and later shown to be effective in the control of Botrytis during post-harvest cold storage of strawberries (Kowalska et al. 2012).

Regarding the mode of antagonism, most of the evidence points to competition for nutrients and space. Culture filtrates do not show any inhibitory activity against $B$. cinerea or $P$. expansum. However, both pathogens show reduced conidial germination and germ tube growth in liquid cocultures (Fan and Tian 2001; Helbig 2002). The addition of glucose or $\mathrm{NH}_{4} \mathrm{NO}_{3}$ to the medium reduces biocontrol ability against $P$. expansum, but not against $B$. cinerea (Lutz et al. 2013). Beside nutrient competition, little conclusive evidence is available to determine a mode of antagonism. $C$. albidus exhibits glucanase, chitinase and protease activity in the corresponding substrate media. It also produces unidentified volatile compounds that inhibit fungal growth and can display killer activity against $C$. glabrata (Lutz et al. 2013). However, none of these mechanisms have been directly linked to the inhibitory activity of the target plant pathogens.

\section{Saccharomyces cerevisiae}

S. cerevisiae is mainly known as a model organism for cell biology, its biotechnological usage, and most importantly the application in food and beverage production. Envisioning $S$. cerevisiae for biocontrol may be motivated by its perception as a safe organism that can be more easily registered, 
but also by its model organism status and the feasibility of molecular analyses. Overall, the model $S$. cerevisiae isolate BY4741 exhibited an intermediate antifungal activity against filamentous fungi and in comparison to a broad collection of wild yeast isolates (Hilber-Bodmer et al. 2017). This laboratory strain is thus ideally suited as a model host to express genes potentially involved in biocontrol activity and thereby improving or weakening its antifungal action.

A number of $S$. cerevisiae strains (e.g., DISAABA1182, RC008, RC009, RC012, and RC016) reduced the growth of plant pathogens such as A. carbonarius, A. ochraceus, A. parasiticus or Fusarium graminearum and also inhibited mycotoxin (e.g., aflatoxin, ochratoxin A, zearalenone, deoxynivalenol) production by these species (Armando et al. 2012a, 2013; Cubaiu et al. 2012). The mycotoxin-removing activity is due to adsorption to $S$. cerevisiae cell walls, stress responses to the toxin (e.g., changes in plasma membrane composition following patulin exposure), as well as direct transcriptional downregulation of polyketide synthesis (Armando et al. 2012b; Cubaiu et al. 2012; Oporto et al. 2019). Other biocontrol mechanisms employed by S. cerevisiae include the secretion of killer activity and hydrolytic enzymes as well as organic volatile compounds in yeasts that have been described and studied with respect to their antifungal activity against $C$. acutatum on citrus (Lopes et al. 2015) (also see Supplementary Table 1). Volatiles in general and specific compounds (e.g., alcohols and esters), were also identified in S. cerevisiae and implicated in the biocontrol activity against the citrus black spot disease caused by Guignardia citricarpa or postharvest decay in strawberries (Fialho et al. 2010; Oro et al. 2017). Seed, soil or foliar applications of a dried, active $S$. cerevisiae preparation also had a plant growth promoting effect and showed biocontrol activity against soilborne fungal pathogens such as Fusarium, Sclerotium or Rhizoctonia (Shalaby and ElNady 2008). Finally, comprehensive transcriptome analyses have confirmed that the application of a cell wall preparation of the $S$. cerevisiae strain LAS117 (i.e., cerevisane ${ }^{\circledR}$ ) induces the expression of genes involved in the plant response to fungal attack (De Miccolis Angelini et al. 2019). S. cerevisiae is therefore considered a promising biocontrol and probiotic organism for reducing growth of fungal pathogens and mycotoxins in fruit, vegetable and feedstuff (Cubaiu et al. 2012; Dogi et al. 2011; Pizzolitto et al. 2012; Prado et al. 2011). However, the only registered, active compound and commercial biocontrol application of Brewer's yeast ( $S$. cerevisiae) is the product Romeo ${ }^{\circledR}$ with cerevisane ${ }^{\circledR}$ as the active ingredient (European Food Safety Authority (EFSA) 2015b). This preparation is used as a preventive inducer of systemic resistance against powdery and downy mildew in grapes, fruits and vegetables and thus represents an application and plant protection product that differs from other such solutions insofar it is not based on active, living cells.

\section{Conclusions and outlook}

The disparity between the number of yeast species exerting biocontrol activity against specific plant pathogens in laboratory assays and the number of yeast that are actually registered and successfully employed as plant protection products is likely caused by the lack of mechanistic understanding, the costs of registration, the lack of partners/consortia with required expertise, or a limited commercial potential. However, the general trend towards reduced pesticide use will certainly favour and create more incentives for the development of alternative plant protection solutions such as biocontrol yeasts. In the environment, these organisms interact intraspecifically, as well as with other microbes (including, but not exclusively, with plant pathogens) and host plants. These complex interactions and interdependencies eventually determine whether a disease sets in or an antagonistic yeast suppresses a pathogen and supports plant health. It is impossible to manage-for plant protection applicationssuch complex interactions without detailed knowledge of the interacting bionts. By studying and identifying modes of action in the laboratory, a reductionist approach is thus an important first step in the development and successful application of biocontrol in general.

Nowadays, the breakthrough achievements in the field of system biology, molecular biology and the related computational tools enable revealing the structural and functional peculiarities of any potential biocontrol agent. Exploiting these tools for the investigation and prediction of functional dynamics occurring between antagonists opens new avenues for the design of consortia of microbial antagonists that synergistically cooperate for the biocontrol of plant pathogens. Although strain mixtures for the biocontrol of plant pathogens are already available commercially (e.g., Blossom- and Boni-Protect ${ }^{\circledR}$, see above) and described in the literature (Heydari and Pessarakli 2010; Lopes et al. 2012; Spadaro and Gullino 2005), employment of taxonomically divergent, but functionally complementary strains might represent a promising approach to follow in the near future in an attempt to design a standardised, multi-targeted, efficacious biocontrol strategy.

A deep mechanistic insight does not guarantee a successful product development and registration, but we argue that fundamental research on biocontrol mechanisms is a key aspect for successful biocontrol applications and at the same time still a frontier in biocontrol research. Hardly any antagonistic mechanism employed by biocontrol yeasts is understood and unequivocally proven by gene deletions and overexpression. This lack of fundamental understanding is also one of the reasons why, so far, little efforts were undertaken to improve, either by selection or molecular tools, biocontrol yeasts for plant protection. In general, molecular tools (e.g., 
gene deletion or overexpression, introduction of trans-genes, synthetic biology techniques) were rarely used in biocontrol yeasts, even though these technologies have the potential to empower studying and understanding these organisms at a whole new level (Marchand et al. 2007). Probably the first "biocontrol engineering example" among yeasts is a S. cerevisiae strain expressing the antifungal peptide cecropin A, which resulted in complete inhibition of Colletotrichum coccodes growth on tomatoes (Jones and Prusky 2002). Cecropin A was also expressed in Pichia pastoris, generating a strain controlling apple blue mold caused by $P$. expansum (Ren et al. 2012). A P. pastoris strain was also engineered for improved control of $P$. expansum by expressing the recombinant peach and pea defensins rDFN1 or rPsd1, respectively (Janisiewicz et al. 2008; Wisniewski et al. 2003). Besides this, only killer toxin activity has been extensively studied and transferred to new strains; mainly for biotechnological applications (Bajaj and Sharma 2010; Bussey et al. 1988; Schmitt and Schernikau 1997). Although the current legislation forbids the deliberate release of genetically manipulated microbials in the environment, model yeasts could also be engineered to shed light on the molecular mechanisms governing their antagonistic capability, their persistence on the host plant, or to better understand how to limit their capability to spread and interbreed (Callaway 2018; Goold et al. 2018; Klemsdal and Tronsmo 1999; Maselko et al. 2017).

Another frontier for biocontrol yeast research is the application in soil, for the protection against soilborne plant pathogens. Phyllosphere applications, particularly the use of yeasts against postharvest diseases, have been identified as the most promising target (Wisniewski et al. 2007). However, a broad range of yeast species occur predominantly in soil, exhibit strong antifungal activity, and could be envisioned as plant protection agents in this environment (Botha 2011; Hilber-Bodmer et al. 2017; Yurkov 2018). Developing yeasts as biocontrol agents against soilborne plant diseases is also attractive, because only few control options are available for the many severe soilborne plant diseases.

The development of a (yeast) biocontrol product depends on a chain of activities and disciplines, from science to industry and legislation, which have to come together, interact and build upon one another. Strengthening the exchange and interaction among these disciplines is thus essential to foster the commercialisation of biocontrol products (Usall et al. 2016). However, establishing such a virtuous cycle is difficult because of the different interests and qualities required and can be further hampered by economic constraints, commercial interests (and thereby a hesitation to share know-how or even material), or a lack of actors with complementary expertise. Considering the fact that many biocontrol solutions are local endeavours, have a limited potential to incur financial gains (in particular in comparison to medical applications), and are somehow idealistic in nature, commercial interests may actually rather harm than benefit the development of commercial biocontrol solutions. In particular, governmental research institutions, engaging in fundamental and applied research and being less driven by commercialisation, may take up a crucial spot for developing biocontrol solutions in the future.

Acknowledgements FMF acknowledges funding from the Swiss National Science Foundation (SNSF, Grant 31003A_175665/1). This paper is dedicated to the memory of Enrico Berardi, sailor, dreamer, and yeast geneticist.

Open Access This article is distributed under the terms of the Creative Commons Attribution 4.0 International License (http://creativeco mmons.org/licenses/by/4.0/), which permits unrestricted use, distribution, and reproduction in any medium, provided you give appropriate credit to the original author(s) and the source, provide a link to the Creative Commons license, and indicate if changes were made.

\section{References}

Abadias M, Teixido N, Usall J, Viñas I, Magan N (2000) Solute stresses affect growth patterns, endogenous water potentials and accumulation of sugars and sugar alcohols in cells of the biocontrol yeast Candida sake. J Appl Microbiol 89:1009-1017. https://doi.org/1 0.1046/j.1365-2672.2000.01207.x

Abadias M, Benabarre A, Teixido N, Usall J, Viñas I (2001a) Effect of freeze drying and protectants on viability of the biocontrol yeast Candida sake. Int J Food Microbiol 65:173-182. https:// doi.org/10.1016/S0168-1605(00)00513-4

Abadias M, Teixido N, Usall J, Benabarre A, Viñas I (2001b) Viability, efficacy, and storage stability of freeze-dried biocontrol agent Candida sake using different protective and rehydration media. J Food Prot 64:856-861. https://doi. org/10.4315/0362-028X-64.6.856

Abadias M, Teixido N, Usall J, Viñas I, Magan N (2001c) Improving water stress tolerance of the biocontrol yeast Candida sake grown in molasses-based media by physiological manipulation. Can $\mathrm{J}$ Microbiol 47:123-129

Abadias M, Teixido N, Usall J, Viñas I (2003) Optimization of growth conditions of the postharvest biocontrol agent Candida sake CPA-1 in a lab-scale fermenter. J Appl Microbiol 95:301-309

Adams DJ (2004) Fungal cell wall chitinases and glucanases. Microbiology 150:2029-2035. https://doi.org/10.1099/mic.0.26980-0

Akgun Karabulut O, Smilanick J, Mlikota Gabler F, Mansour M, Droby S (2003) Near-harvest applications of Metschnikowia fructicola, ethanol, and sodium bicarbonate to control postharvest diseases of grape in central California. Plant Dis 87:1384-1389. https:// doi.org/10.1094/PDIS.2003.87.11.1384

Ali S, Huang Z, Ren SX (2009) Production and extraction of extracellular lipase from the entomopathogenic fungus Isaria fumosoroseus (Cordycipitaceae; Hypocreales). Biocontrol Sci Technol 19:81-89. https://doi.org/10.1080/09583150802588524

Armando MR, Dogi CA, Rosa CA, Dalcero AM, Cavaglieri LR (2012a) Saccharomyces cerevisiae strains and the reduction of Aspergillus parasiticus growth and aflatoxin B1 production at different interacting environmental conditions, in vitro. Food Addit Contam Part A 29:1443-1449. https://doi.org/10.1080/19440 049.2012 .698655

Armando MR et al (2012b) Adsorption of ochratoxin A and zearalenone by potential probiotic Saccharomyces cerevisiae strains and 
its relation with cell wall thickness. J Appl Microbiol 113:256264. https://doi.org/10.1111/j.1365-2672.2012.05331.x

Armando MR, Dogi CA, Poloni V, Rosa CA, Dalcero AM, Cavaglieri LR (2013) In vitro study on the effect of Saccharomyces cerevisiae strains on growth and mycotoxin production by Aspergillus carbonarius and Fusarium graminearum. Int J Food Microbiol 161:182-188. https://doi.org/10.1016/j.ijfoodmicro.2012.11.016

Arrarte E, Garmendia G, Rossini C, Wisniewski M, Vero S (2017) Volatile organic compounds produced by Antarctic strains of Candida sake play a role in the control of postharvest pathogens of apples. Biol Control 109:14-20. https://doi.org/10.1016/j. biocontrol.2017.03.002

Arras G, Molinu MG, Dore A, Venditti T, Fois M, Petretto A, D'Hallewin G (2006) Inhibitory activity of 2-deoxy-D-glucose and Candida saitoana against Penicillium digitatum. Commun Agric Appl Biol Sci 71:929-936

Arras G et al (2010) Synergic interactions between 2-deoxy-D-glucose and Candida saitoana enhances citrus green mould control. Commun Agric Appl Biol Sci 75:555-562

Arroyo-Lopez FN, Querol A, Bautista-Gallego J, Garrido-Fernandez A (2008) Role of yeasts in table olive production. Int J Food Microbiol 128:189-196. https://doi.org/10.1016/j.ijfoodmicr o.2008.08.018

Bajaj BK, Sharma S (2010) Construction of killer industrial yeast Saccharomyces cerevisiae hau-1 and its fermentation performance. Braz J Microbiol 41:477-485. https://doi.org/10.1590/S1517 $-838220100002000030$

Bajaj BK, Raina S, Singh S (2013) Killer toxin from a novel killer yeast Pichia kudriavzevii RY55 with idiosyncratic antibacterial activity. J Basic Microbiol 53:645-656. https://doi.org/10.1002/ jobm. 201200187

Banani H, Spadaro D, Zhang D, Matic S, Garibaldi A, Gullino ML (2014) Biocontrol activity of an alkaline serine protease from Aureobasidium pullulans expressed in Pichia pastoris against four postharvest pathogens on apple. Int J Food Microbiol 182183:1-8. https://doi.org/10.1016/j.ijfoodmicro.2014.05.001

Banani H, Spadaro D, Zhang D, Matic S, Garibaldi A, Gullino ML (2015) Postharvest application of a novel chitinase cloned from Metschnikowia fructicola and overexpressed in Pichia pastoris to control brown rot of peaches. Int J Food Microbiol 199:54-61. https://doi.org/10.1016/j.ijfoodmicro.2015.01.002

Banjara N, Nickerson KW, Suhr MJ, Hallen-Adams HE (2016) Killer toxin from several food-derived Debaryomyces hansenii strains effective against pathogenic Candida yeasts. Int J Food Microbiol 222:23-29. https://doi.org/10.1016/j.ijfoodmicro.2016.01.016

Barber MF, Elde NC (2015) Buried treasure: evolutionary perspectives on microbial iron piracy. Trends Genet 31:627-636. https://doi. org/10.1016/j.tig.2015.09.001

Barda O, Shalev O, Alster S, Buxdorf K, Gafni A, Levy M (2015) Pseudozyma aphidis induces salicylic-acid-independent resistance to Clavibacter michiganensis in tomato plants. Plant Dis 99:621-626. https://doi.org/10.1094/PDIS-04-14-0377-RE

Bar-Shimon M et al (2004) Characterization of extracellular lytic enzymes produced by the yeast biocontrol agent Candida oleophila. Curr Genet 45:140-148. https://doi.org/10.1007/s0029 4-003-0471-7

Bekatorou A, Psarianos C, Koutinas AA (2006) Production of food grade yeasts. Food Technol Biotechnol 44:407-415

Belda I, Ruiz J, Alonso A, Marquina D, Santos A (2017) The biology of Pichia membranifaciens killer toxins. Toxins (Basel). https:// doi.org/10.3390/toxins 9040112

Berto P, Jijakli MH, Lepoivre P (2001) Possible role of colonization and cell wall-degrading enzymes in the differential ability of three Ulocladium atrum strains to control Botrytis cinerea on necrotic strawberry leaves. Phytopathology 91:1030-1036. https ://doi.org/10.1094/PHYTO.2001.91.11.1030
Beys da Silva WO, Santi L, Correa AP, Silva LA, Bresciani FR, Schrank A, Vainstein MH (2010a) The entomopathogen Metarhizium anisopliae can modulate the secretion of lipolytic enzymes in response to different substrates including components of arthropod cuticle. Fungal Biol 114:911-916. https://doi. org/10.1016/j.funbio.2010.08.007

Beys da Silva WO, Santi L, Schrank A, Vainstein MH (2010b) Metarhizium anisopliae lipolytic activity plays a pivotal role in Rhipicephalus (Boophilus) microplus infection. Fungal Biol 114:10 15. https://doi.org/10.1016/j.mycres.2009.08.003

Białkowska A, Turkiewicz M (2014) Miscellaneous cold-active yeast enzymes of industrial importance. In: Buzzini P, Margesin R (eds) Cold-adapted yeasts: biodiversity, adaptation strategies and biotechnological significance. Springer, Berlin, pp 377-395. https://doi.org/10.1007/978-3-642-39681-6_17

Botha A (2011) The importance and ecology of yeasts in soil. Soil Biol Biochem 43:1-8. https://doi.org/10.1016/j.soilbio.2010.10.001

Breuer U, Harms H (2006) Debaryomyces hansenii-an extremophilic yeast with biotechnological potential. Yeast 23:415-437. https ://doi.org/10.1002/yea.1374

Bruce A, Stewart D, Verrall S, Wheatley RE (2003) Effect of volatiles from bacteria and yeast on the growth and pigmentation of sapstain fungi. Int Biodeterior Biodegrad 51:101-108. https://doi. org/10.1016/S0964-8305(02)00088-4

Bussey H, Vernet T, Sdicu AM (1988) Mutual antagonism among killer yeasts: competition between $\mathrm{K} 1$ and $\mathrm{K} 2$ killers and a novel cDNA-based K1-K2 killer strain of Saccharomyces cerevisiae. Can J Microbiol 34:38-44

Butler G et al (2009) Evolution of pathogenicity and sexual reproduction in eight Candida genomes. Nature 459:657-662. https://doi. org/10.1038/nature08064

Buxdorf K, Rahat I, Gafni A, Levy M (2013a) The epiphytic fungus Pseudozyma aphidis induces jasmonic acid- and salicylic acid/ nonexpressor of PR1-independent local and systemic resistance. Plant Physiol 161:2014-2022. https://doi.org/10.1104/ pp.112.212969

Buxdorf K, Rahat I, Levy M (2013b) Pseudozyma aphidis induces ethylene-independent resistance in plants. Plant Signal Behav 8:e26273. https://doi.org/10.4161/psb.26273

Buzdar MA, Chi Z, Wang Q, Hua MX, Chi ZM (2011) Production, purification, and characterization of a novel killer toxin from Kluyveromyces siamensis against a pathogenic yeast in crab. Appl Microbiol Biotechnol 91:1571-1579. https://doi. org/10.1007/s00253-011-3220-8

Buzzini P, Martini A (2002) Extracellular enzymatic activity profiles in yeast and yeast-like strains isolated from tropical environments. J Appl Microbiol 93:1020-1025. https://doi.org/10.104 6/j.1365-2672.2002.01783.x

Buzzini P, Corazzi L, Turchetti B, Buratta M, Martini A (2004) Characterization of the in vitro antimycotic activity of a novel killer protein from Williopsis saturnus DBVPG 4561 against emerging pathogenic yeasts. FEMS Microbiol Lett 238:359-365. https:// doi.org/10.1016/j.femsle.2004.07.060

Cabral V et al (2014) Targeted changes of the cell wall proteome influence Candida albicans ability to form single- and multi-strain biofilms. PLoS Pathog 10:e1004542. https://doi.org/10.1371/ journal.ppat. 1004542

Calderon CE, Rotem N, Harris R, Vela-Corcia D, Levy M (2019) Pseudozyma aphidis activates reactive oxygen species production, programmed cell death and morphological alterations in the necrotrophic fungus Botrytis cinerea. Mol Plant Pathol 20:562574. https://doi.org/10.1111/mpp.12775

Callaway E (2018) Synthetic species made to shun sex with wild organisms. Nature 553:259-260. https://doi.org/10.1038/d41586-01800625-1 
Calvo-Garrido C, Viñas I, Elmer P, Usall J, Teixido N (2013) Candida sake CPA-1 and other biologically based products as potential control strategies to reduce sour rot of grapes. Lett Appl Microbiol 57:356-361. https://doi.org/10.1111/lam.12121

Canamas TP, Viñas I, Usall J, Magan N, Solsona C, Teixido N (2008) Impact of mild heat treatments on induction of thermotolerance in the biocontrol yeast Candida sake CPA-1 and viability after spray-drying. J Appl Microbiol 104:767-775. https://doi.org/10 $.1111 / \mathrm{j} .1365-2672.2007 .03590 . \mathrm{x}$

Cao M, Gao M, Lopez-Garcia CL, Wu Y, Seetharam AS, Severin AJ, Shao Z (2017) Centromeric DNA facilitates nonconventional yeast genetic engineering. ACS Synth Biol 6:1545-1553. https ://doi.org/10.1021/acssynbio.7b00046

Carbo A, Torres R, Teixido N, Usall J, Medina A, Magan N (2018) Impact of climate change environmental conditions on the resilience of different formulations of the biocontrol agent Candida sake CPA-1 on grapes. Lett Appl Microbiol. https://doi. org/10.1111/lam.12889

Castoria R, De Curtis F, Lima G, De Cicco V (1997) $\beta$-1,3-glucanase activity of two saprophytic yeasts and possible mode of action as biocontrol agents against postharvest diseases. Postharvest Biol Technol 12:293-300. https://doi.org/10.1016/S0925 -5214(97)00061-6

Cavalheiro M, Teixeira MC (2018) Candida biofilms: threats, challenges, and promising strategies. Front Med (Lausanne) 5:28. https://doi.org/10.3389/fmed.2018.00028

Chan Z, Tian S (2005) Interaction of antagonistic yeasts against postharvest pathogens of apple fruit and possible mode of action. Postharvest Biol Technol 36:215-223. https://doi.org/10.1016/j. postharvbio.2005.01.001

Chappell CR, Fukami T (2018) Nectar yeasts: a natural microcosm for ecology. Yeast 35:417-423. https://doi.org/10.1002/yea.3311

Chen WB, Han YF, Jong SC, Chang SC (2000) Isolation, purification, and characterization of a killer protein from Schwanniomyces occidentalis. Appl Environ Microbiol 66:5348-5352. https://doi. org/10.1128/aem.66.12.5348-5352.2000

Chessa R et al (2017) Biotechnological exploitation of Tetrapisispora phaffii killer toxin: heterologous production in Komagataella phaffii (Pichia pastoris). Appl Microbiol Biotechnol 101:29312942. https://doi.org/10.1007/s00253-016-8050-2

Chi ZM, Liu G, Zhao S, Li J, Peng Y (2010) Marine yeasts as biocontrol agents and producers of bio-products. Appl Microbiol Biotechnol 86:1227-1241. https://doi.org/10.1007/s0025 3-010-2483-9

Chi $\mathrm{M}$ et al (2015) Increase in antioxidant enzyme activity, stress tolerance and biocontrol efficacy of Pichia kudriavzevii with the transition from a yeast-like to biofilm morphology. Biol Cont 90:113-119. https://doi.org/10.1016/j.biocontrol.2015.06.006

Chisholm ST, Coaker G, Day B, Staskawicz BJ (2006) Host-microbe interactions: shaping the evolution of the plant immune response. Cell 124:803-814. https://doi.org/10.1016/j.cell.2006.02.008

Coelho AR, Tachi M, Pagnocca FC, Nobrega GM, Hoffmann FL, Harada K, Hirooka EY (2009) Purification of Candida guilliermondii and Pichia ohmeri killer toxin as an active agent against Penicillium expansum. Food Addit Contam Part A 26:73-81. https://doi.org/10.1080/02652030802227227

Comitini F, Ciani M (2011) Kluyveromyces wickerhamii killer toxin: purification and activity towards Brettanomyces/Dekkera yeasts in grape must. FEMS Microbiol Lett 316:77-82. https://doi.org /10.1111/j.1574-6968.2010.02194.x

Comitini F, Di Pietro N, Zacchi L, Mannazzu I, Ciani M (2004) Kluyveromyces phaffii killer toxin active against wine spoilage yeasts: purification and characterization. Microbiology 150:2535-2541. https://doi.org/10.1099/mic.0.27145-0

Corbaci C, Ucar FB (2018) Purification, characterization and in vivo biocontrol efficiency of killer toxins from Debaryomyces hansenii strains. Int J Biol Macromol 119:1077-1082. https:// doi.org/10.1016/j.ijbiomac.2018.07.121

Costa-Orlandi CB et al (2017) Fungal biofilms and polymicrobial diseases. J Fungi (Basel) 3:22. https://doi.org/10.3390/jof3020022

Cubaiu L, Abbas H, Dobson AD, Budroni M, Migheli Q (2012) A Saccharomyces cerevisiae wine strain inhibits growth and decreases ochratoxin A biosynthesis by Aspergillus carbonarius and Aspergillus ochraceus. Toxins (Basel) 4:1468-1481. https://doi. org/10.3390/toxins 4121468

da Silva S, Calado S, Lucas C, Aguiar C (2008) Unusual properties of the halotolerant yeast Candida nodaensis killer toxin, CnKT. Microbiol Res 163:243-251. https://doi.org/10.1016/j.micre s.2007.04.002

Dahiya N, Tewari R, Hoondal GS (2006) Biotechnological aspects of chitinolytic enzymes: a review. Appl Microbiol Biotechnol 71:773-782. https://doi.org/10.1007/s00253-005-0183-7

Davey ME, O'Toole GA (2000) Microbial biofilms: from ecology to molecular genetics. Microbiol Mol Biol Rev 64:847-867. https ://doi.org/10.1128/mmbr.64.4.847-867.2000

De Ingeniis J, Raffaelli N, Ciani M, Mannazzu I (2009) Pichia anomala DBVPG 3003 secretes a ubiquitin-like protein that has antimicrobial activity. Appl Environ Microbiol 75:1129-1134. https:// doi.org/10.1128/AEM.01837-08

De Miccolis Angelini RM, Rotolo C, Gerin D, Abate D, Pollastro S, Faretra F (2019) Global transcriptome analysis and differentially expressed genes in grapevine after application of the yeastderived defense inducer cerevisane. Pest Manag Sci 75:2020 2033. https://doi.org/10.1002/ps.5317

d'Enfert C, Janbon G (2016) Biofilm formation in Candida glabrata: what have we learnt from functional genomics approaches? FEMS Yeast Res 16:fov111. https://doi.org/10.1093/femsyr/ fov111

Desai JV, Mitchell AP, Andes DR (2014) Fungal biofilms, drug resistance, and recurrent infection. Cold Spring Harb Perspect Med. https://doi.org/10.1101/cshperspect.a019729

Dhami MK, Hartwig T, Fukami T (2016) Genetic basis of priority effects: insights from nectar yeast. Proc Biol Sci. https://doi. org/10.1098/rspb.2016.1455

Di Francesco A, Ugolini L, Lazzeri L, Mari M (2014) Production of volatile organic compounds by Aureobasidium pullulans as a potential mechanism of action against postharvest fruit pathogens. Biol Control 81:8-14. https://doi.org/10.1016/j.biocontrol .2014 .10 .004

Dogi CA, Armando R, Luduena R, de Moreno de LeBlanc A, Rosa CA, Dalcero A, Cavaglieri L (2011) Saccharomyces cerevisiae strains retain their viability and aflatoxin $\mathrm{B} 1$ binding ability under gastrointestinal conditions and improve ruminal fermentation. Food Addit Contam Part A 28:1705-1711. https://doi. org/10.1080/19440049.2011.605771

Droby S, Chalutz E (1994) Mode of action of biocontrol agents of postharvest diseases. In: Wilson CL, Wisniewski ME (eds) Biological control of postharvest diseases: theory and practice. CRC Press Inc, Boca Raton, pp 63-75

Droby S, El-Gerberia B (2006) Yeast Metschnikowia fructicola NRRL Y-30752 for inhibiting deleterious microorganisms on plants. USA Patent, 7 Feb 2006

Droby S et al (1998) Commercial testing of Aspire: a yeast preparation for the biological control of postharvest decay of citrus. Biol Control 12:97-101

Droby S, Vinokur V, Weiss B, Cohen L, Daus A, Goldschmidt EE, Porat R (2002) Induction of resistance to Penicillium digitatum in grapefruit by the yeast biocontrol agent Candida oleophila. Phytopathology 92:393-399. https://doi.org/10.1094/PHYTO .2002.92.4.393

Droby S, Wisniewski M, El-Ghaouth A, Wilson C (2003) Biological control of postharvest diseases of fruit and vegetables: current 
achievements and future challenges. In: International Society for Horticultural Science (ISHS), Leuven, Belgium, pp 703-713. https://doi.org/10.17660/actahortic.2003.628.89

Droby S, Wisniewski M, El Ghaouth A, Wilson C (2003b) Influence of food additives on the control of postharvest rots of apple and peach and efficacy of the yeast-based biocontrol product aspire. Postharvest Biol Tec 27:127-135. https://doi.org/10.1016/S0925 -5214(02)00046-7

Droby S, Wisniewski M, Macarisin D, Wilson C (2009) Twenty years of postharvest biocontrol research: is it time for a new paradigm? Postharvest Biol Technol 52:137-145. https://doi.org/10.1016/j. postharvbio.2008.11.009

El Ghaouth A, Wilson CL, Wisniewski M (2003) Control of postharvest decay of apple fruit with Candida saitoana and induction of defense responses. Phytopathology 93:344-348. https://doi. org/10.1094/PHYTO.2003.93.3.344

Elad Y, Köhl J, Fokkema N (1994) Control of infection and sporulation of Botrytis cinerea on bean and tomato by saprophytic yeasts. Phytopathology 84:1193-1200

El-Ghaouth A, Wilson C (2002) Candida saitoana compositions for biocontrol of plant postharvest decay USA Patent

El-Ghaouth A, Wilson CL, Wisniewski M (1998) Ultrastructural and cytochemical aspects of the biological control of Botrytis cinerea by Candida saitoana in apple fruit. Phytopathology 88:282-291. https://doi.org/10.1094/PHYTO.1998.88.4.282

El-Ghaouth A, Smilanick JL, Brown GE, Ippolito A, Wisniewski M, Wilson CL (2000a) Application of Candida saitoana and glycolchitosan for the control of postharvest diseases of apple and citrus fruit under semi-commercial conditions. Plant Dis 84:243248. https://doi.org/10.1094/Pdis.2000.84.3.243

El-Ghaouth A, Smilanick JL, Wilson CL (2000b) Enhancement of the performance of Candida saitoana by the addition of glycolchitosan for the control of postharvest decay of apple and citrus fruit. Postharvest Biol Technol 19:103-110. https://doi. org/10.1016/S0925-5214(00)00076-4

El-Ghaouth A, Smilanick JL, Wisniewski M, Wilson CL (2000c) Improved control of apple and citrus fruit decay with a combination of Candida saitoana and 2-deoxy-D-glucose. Plant Dis 84:249-253. https://doi.org/10.1094/Pdis.2000.84.3.249

Eshel D, Regev R, Orenstein J, Droby S, Gan-Mor S (2009) Combining physical, chemical and biological methods for synergistic control of postharvest diseases: a case study of black root rot of carrot. Postharvest Biol Technol 54:48-52. https://doi.org/10.1016/j. postharvbio.2009.04.011

European Commission Health \& Consumers Directorate-General (2013) Review report for the active substance Candida oleophila strain O. vol SANCO/10395/2013 rev 1. https://doi. org/10.2903/j.efsa.2015.4250

European Food Safety Authority (2005) Opinion of the Scientific Committee on a request from EFSA related to a generic approach to the safety assessment by EFSA of microorganisms used in food/ feed and the production of food/feed additives. EFSA J 3:226. https://doi.org/10.2903/j.efsa.2005.226

European Food Safety Authority (EFSA) (2013) Conclusion on the peer review of the pesticide risk assessment of the active substance Aureobasidium pullulans (strains DSM 14940 and DSM 14941). EFSA J 11:3183. https://doi.org/10.2903/j.efsa.2015.4322

European Food Safety Authority (EFSA) (2015a) Conclusion on the peer review of the pesticide risk assessment of the active substance Candida oleophila strain O. EFSA J 10:2944. https://doi. org/10.2903/j.efsa.2015.4250

European Food Safety Authority (EFSA) (2015b) Peer review of the pesticide risk assessment of the active substance Saccharomyces cerevisiae strain LAS02. EFSA J 13:4322. https://doi. org/10.2903/j.efsa.2015.4322
European Food Safety Authority (EFSA) (2015c) Public consultation on the active substance Metschnikowia fructicola NRRL Y-27328 EFSA Rapporteur Assessment Report

European Food Safety Authority (EFSA) (2017) Peer review of the pesticide risk assessment of the active substance Metschnikowia fructicola NRRL Y-27328. EFSA J 15:5084. https://doi. org/10.2903/j.efsa.2017.5084

Fan Q, Tian S (2001) Postharvest biological control of grey mold and blue mold on apple by Cryptococcus albidus (Saito) Skinner. Postharvest Biol Technol 21:341-350. https://doi.org/10.1016/ S0925-5214(00)00182-4

Fanning S, Mitchell AP (2012) Fungal biofilms. PLoS Pathog 8:e1002585. https://doi.org/10.1371/journal.ppat.1002585

Farbo MG et al (2018) Effect of yeast volatile organic compounds on ochratoxin A-producing Aspergillus carbonarius and A. ochraceus. Int J Food Microbiol 284:1-10. https://doi.org/10.1016/j. ijfoodmicro.2018.06.023

Fialho MB, Toffano L, Pedroso MP, Augusto F, Pascholati SF (2010) Volatile organic compounds produced by Saccharomyces cerevisiae inhibit the in vitro development of Guignardia citricarpa, the causal agent of citrus black spot. World J Microb Biot 26:925-932. https://doi.org/10.1007/s11274-009-0255-4

Fiori S, Fadda A, Giobbe S, Berardi E, Migheli Q (2008) Pichia angusta is an effective biocontrol yeast against postharvest decay of apple fruit caused by Botrytis cinerea and Monilia fructicola. FEMS Yeast Res 8:961-963. https://doi.org/10.111 1/j.1567-1364.2008.00424.x

Fiori $\mathrm{S}$ et al (2012) Identification of differentially expressed genes associated with changes in the morphology of Pichia fermentans on apple and peach fruit. FEMS Yeast Res 12:785-795. https://doi. org/10.1111/j.1567-1364.2012.00829.x

Fiori S, Urgeghe PP, Hammami W, Razzu S, Jaoua S, Migheli Q (2014) Biocontrol activity of four non- and low-fermenting yeast strains against Aspergillus carbonarius and their ability to remove ochratoxin A from grape juice. Int J Food Microbiol 189:45-50. https://doi.org/10.1016/j.ijfoodmicro.2014.07.020

Fitzpatrick DA (2012) Horizontal gene transfer in fungi. FEMS Microbiol Lett 329:1-8. https://doi.org/10.111 1/j.1574-6968.2011.02465.x

Friel D, Pessoa NM, Vandenbol M, Jijakli MH (2007) Separate and combined disruptions of two exo- $\beta$-1,3-glucanase genes decrease the efficiency of Pichia anomala (strain K) biocontrol against Botrytis cinerea on apple. Mol Plant Microbe Interact 20:371379. https://doi.org/10.1094/MPMI-20-4-0371

Gafni A, Calderon CE, Harris R, Buxdorf K, Dafa-Berger A, ZeilingerReichert E, Levy M (2015) Biological control of the cucurbit powdery mildew pathogen Podosphaera xanthii by means of the epiphytic fungus Pseudozyma aphidis and parasitism as a mode of action. Front Plant Sci 6:132. https://doi.org/10.3389/ fpls.2015.00132

Gamagae SU, Sivakumar D, Wijeratnam RSW, Wijesundera RLC (2003) Use of sodium bicarbonate and Candida oleophila to control anthracnose in papaya during storage. Crop Prot 22:775-779. https://doi.org/10.1016/S0261-2194(03)00046-2

Gauthier GM (2015) Dimorphism in fungal pathogens of mammals, plants, and insects. PLoS Pathog 11:e1004608. https://doi. org/10.1371/journal.ppat. 1004608

Gauthier GM (2017) Fungal dimorphism and virulence: molecular mechanisms for temperature adaptation, immune evasion, and in vivo survival. Mediators Inflamm 2017:8491383. https://doi. org/10.1155/2017/8491383

Giobbe S, Marceddu S, Scherm B, Zara G, Mazzarello VL, Budroni M, Migheli Q (2007) The strange case of a biofilm-forming strain of Pichia fermentans, which controls Monilinia brown rot on apple but is pathogenic on peach fruit. FEMS Yeast Res 7:1389-1398. https://doi.org/10.1111/j.1567-1364.2007.00301.x 
Golubev WI, Pfeiffer I, Golubeva EW (2006) Mycocin production in Pseudozyma tsukubaensis. Mycopathologia 162:313-316. https ://doi.org/10.1007/s11046-006-0065-2

Goold HD, Wright P, Hailstones D (2018) Emerging opportunities for synthetic biology in agriculture. Genes (Basel) 9:E341. https:// doi.org/10.3390/genes 9070341

Gore-Lloyd D et al (2019) Snf2 controls pulcherriminic acid biosynthesis and antifungal activity of the biocontrol yeast Metschnikowia pulcherrima. Mol Microbiol 112:317-332. https ://doi.org/10.1111/mmi.14272

Gozzo F, Faoro F (2013) Systemic acquired resistance (50 years after discovery): moving from the lab to the field. J Agric Food Chem 61:12473-12491. https://doi.org/10.1021/jf404156x

Grevesse C, Lepoivre P, Jijakli MH (2003) Characterization of the exoglucanase-encoding gene PaEXG2 and study of its role in the biocontrol activity of Pichia anomala strain K. Phytopathology 93:1145-1152. https://doi.org/10.1094/PHYTO.2003.93.9.1145

Guo FJ, Ma Y, Xu HM, Wang XH, Chi ZM (2013) A novel killer toxin produced by the marine-derived yeast Wickerhamomyces anomalus YF07b. Antonie Van Leeuwenhoek 103:737-746. https:// doi.org/10.1007/s10482-012-9855-3

Guyard C, Dehecq E, Tissier JP, Polonelli L, Dei-Cas E, Cailliez JC, Menozzi FD (2002a) Involvement of [beta]-glucans in the widespectrum antimicrobial activity of Williopsis saturnus var. mrakii MUCL 41968 killer toxin. Mol Med 8:686-694

Guyard C et al (2002b) Characterization of a Williopsis saturnus var. mrakii high molecular weight secreted killer toxin with broad-spectrum antimicrobial activity. J Antimicrob Chemother 49:961-971. https://doi.org/10.1093/jac/dkf040

Hadwiger LA, McDonel H, Glawe D (2015) Wild yeast strains as prospective candidates to induce resistance against potato late blight (Phytophthora infestans). Am J Potato Res 92:379-386. https:// doi.org/10.1007/s12230-015-9443-y

Helbig J (2002) Ability of the antagonistic yeast Cryptococcus albidus to control Botrytis cinerea in strawberry. Biocontrol 47:85-99. https://doi.org/10.1023/A:1014466903941

Hernandez A, Martin A, Aranda E, Perez-Nevado F, Cordoba MG (2007) Identification and characterization of yeast isolated from the elaboration of seasoned green table olives. Food Microbiol 24:346-351. https://doi.org/10.1016/j.fm.2006.07.022

Herrera-Estrella A, Chet I (1999) Chitinases in biological control. EXS 87:171-184

Hershkovitz V et al (2012) Global changes in gene expression of grapefruit peel tissue in response to the yeast biocontrol agent Metschnikowia fructicola. Mol Plant Pathol 13:338-349. https ://doi.org/10.1111/j.1364-3703.2011.00750.x

Hershkovitz V et al (2013) De-novo assembly and characterization of the transcriptome of Metschnikowia fructicola reveals differences in gene expression following interaction with Penicillium digitatum and grapefruit peel. BMC Genom 14:168. https://doi. org/10.1186/1471-2164-14-168

Heydari A, Pessarakli M (2010) A review on biological control of fungal plant pathogens using microbial agents. J Biol Sci 10:273290. https://doi.org/10.3923/jbs.2010.273.290

Hilber-Bodmer M, Schmid M, Ahrens CH, Freimoser FM (2017) Competition assays and physiological experiments of soil and phyllosphere yeasts identify Candida subhashii as a novel antagonist of filamentous fungi. BMC Microbiol 17:4. https://doi.org/10.1186/ s12866-016-0908-z

Holb IJ, Kunz S (2013) Integrated control of brown rot blossom blight by combining approved chemical control options with Aureobasidium pullulans in organic cherry production. Crop Prot 54:114120. https://doi.org/10.1016/j.cropro.2013.07.003

Hua MX, Chi Z, Liu GL, Buzdar MA, Chi ZM (2010) Production of a novel and cold-active killer toxin by Mrakia frigida 2E00797 isolated from sea sediment in Antarctica. Extremophiles 14:515521. https://doi.org/10.1007/s00792-010-0331-6

Hua SS, Beck JJ, Sarreal SB, Gee W (2014) The major volatile compound 2-phenylethanol from the biocontrol yeast, Pichia anomala, inhibits growth and expression of aflatoxin biosynthetic genes of Aspergillus flavus. Mycotoxin Res 30:71-78. https:// doi.org/10.1007/s12550-014-0189-Z

Huang R, Li GQ, Zhang J, Yang L, Che HJ, Jiang DH, Huang HC (2011) Control of postharvest Botrytis fruit rot of strawberry by volatile organic compounds of Candida intermedia. Phytopathology 101:859-869. https://doi.org/10.1094/PHYTO-09-10-0255

Huang R, Che HJ, Zhang J, Yang L, Jiang DH, Li GQ (2012) Evaluation of Sporidiobolus pararoseus strain YCXT3 as biocontrol agent of Botrytis cinerea on post-harvest strawberry fruits. Biol Control 62:53-63. https://doi.org/10.1016/j.biocontrol .2012 .02 .010

Janisiewicz WJ, Pereira IB, Almeida MS, Roberts DP, Wisniewski M, Kurtenbach E (2008) Improved biocontrol of fruit decay fungi with Pichia pastoris recombinant strains expressing Psd1 antifungal peptide. Postharvest Biol Technol 47:218-225. https://doi. org/10.1016/j.postharvbio.2007.06.010

Jiang B, Ram AF, Sheraton J, Klis FM, Bussey H (1995) Regulation of cell wall beta-glucan assembly: $p T C 1$ negatively affects PBS2 action in a pathway that includes modulation of $E X G 1$ transcription. Mol Gen Genet 248:260-269

Johnson L (2008) Iron and siderophores in fungal-host interactions. Mycol Res 112:170-183. https://doi.org/10.1016/j.mycre s.2007.11.012

Jones JD, Dangl JL (2006) The plant immune system. Nature 444:323329. https://doi.org/10.1038/nature05286

Jones RW, Prusky D (2002) Expression of an antifungal peptide in Saccharomyces: a new approach for biological control of the postharvest disease caused by Colletotrichum coccodes. Phytopathology 92:33-37. https://doi.org/10.1094/PHYTO.2002.92.1.33

Junker K, Hesselbart A, Wendland J (2017) Draft genome sequence of Saccharomycopsis fodiens CBS 8332, a necrotrophic mycoparasite with biocontrol potential. Genome Announc. https:// doi.org/10.1128/genomeA.01278-17

Junker K, Bravo Ruiz G, Lorenz A, Walker L, Gow NAR, Wendland J (2018) The mycoparasitic yeast Saccharomycopsis schoenii predates and kills multi-drug resistant Candida auris. Sci Rep 8:14959. https://doi.org/10.1038/s41598-018-33199-z

Junker K, Chailyan A, Hesselbart A, Forster J, Wendland J (2019) Multi-omics characterization of the necrotrophic mycoparasite Saccharomycopsis schoenii. PLoS Pathog 15:e1007692. https ://doi.org/10.1371/journal.ppat.1007692

Kasahara $S$ et al (1994a) Involvement of cell wall beta-glucan in the action of HM-1 killer toxin. FEBS Lett 348:27-32

Kasahara S et al (1994b) Cloning of the Saccharomyces cerevisiae gene whose overexpression overcomes the effects of HM-1 killer toxin, which inhibits beta-glucan synthesis. J Bacteriol 176:1488-1499. https://doi.org/10.1128/ jb.176.5.1488-1499.1994

Keyhani NO (2018) Lipid biology in fungal stress and virulence: entomopathogenic fungi. Fungal Biol 122:420-429. https://doi. org/10.1016/j.funbio.2017.07.003

Klassen R, Teichert S, Meinhardt F (2004) Novel yeast killer toxins provoke S-phase arrest and DNA damage checkpoint activation. Mol Microbiol 53:263-273. https://doi.org/10.111 1/j.1365-2958.2004.04119.x

Klein MN, Kupper KC (2018) Biofilm production by Aureobasidium pullulans improves biocontrol against sour rot in citrus. Food Microbiol 69:1-10. https://doi.org/10.1016/j.fm.2017.07.008

Klemsdal SS, Tronsmo A (1999) Genetic manipulation for improvement of microbial biocontrol agents. In: Albajes R, Gullino ML, van Lenteren JC, Elad Y (eds) Integrated pest and disease 
management in greenhouse crops. Springer, Dordrecht, pp 353364. https://doi.org/10.1007/0-306-47585-5_25

Kombrink A, Sanchez-Vallet A, Thomma BP (2011) The role of chitin detection in plant-pathogen interactions. Microbes Infect 13:1168-1176. https://doi.org/10.1016/j.micinf.2011.07.010

Kowalska J, Drożdżyński D, Remlein-Starosta D, Sas-Paszt L, Malusá E (2012) Use of Cryptococcus albidus for controlling grey mould in the production and storage of organically grown strawberries. J Plant Dis Protect 119:174-178

Kunz S (2004) Development of "Blossom-Protect" - a yeast preparation for the reduction of blossom infections by fire blight. 11th International Conference on Cultivation Technique and Phytopathological problems in organic fruit-growing. Weinsberg, Germany

Kunz S, Haug P (2006) Development of a strategy for fire blight control in organic fruit growing. In: Boos M (ed) 12th International Conference on Cultivation Technique and Phytopathological Probelms in Organic Fruit-Growing, Weinsberg, 2006. Fördergemeinschaft ökologischer Obstbau, pp 113-117

Kunz S, Schmitt A, Haug P (2011) Field testing of strategies for fire blight control in organic fruit growing. Acta Hortic 896:431-436. https://doi.org/10.17660/ActaHortic.2011.896.62

Kurtzman CP, Droby S (2001) Metschnikowia fructicola, a new ascosporic yeast with potential for biocontrol of postharvest fruit rots. Syst Appl Microbiol 24:395-399. https://doi. org/10.1078/0723-2020-00045

Lachance MA, Pang WM (1997) Predacious yeasts. Yeast 13:225-232. https://doi.org/10.1002/(SICI)1097-0061(19970315)13:3\%3c225 :AID-YEA87\%3e3.0.CO;2-I

Lachance MA, Starmer WT, Rosa CA, Bowles JM, Barker JS, Janzen DH (2001) Biogeography of the yeasts of ephemeral flowers and their insects. FEMS Yeast Res 1:1-8. https://doi. org/10.1111/j.1567-1364.2001.tb00007.x

Lahlali R, Serrhini MN, Jijakli MH (2004) Efficacy assessment of Candida oleophila (strain O) and Pichia anomala (strain K) against major postharvest diseases of citrus fruits in Morocco. Commun Agric Appl Biol Sci 69:601-609

Langner T, Gohre V (2015) Fungal chitinases: function, regulation, and potential roles in plant/pathogen interactions. Curr Genet. https://doi.org/10.1007/s00294-015-0530-x

Lee G, Lee SH, Kim KM, Ryu CM (2017) Foliar application of the leaf-colonizing yeast Pseudozyma churashimaensis elicits systemic defense of pepper against bacterial and viral pathogens. Sci Rep 7:39432. https://doi.org/10.1038/srep39432

Lemos WJ Jr et al (2016) Biocontrol ability and action mechanism of Starmerella bacillaris (synonym Candida zemplinina) isolated from wine musts against gray mold disease agent Botrytis cinerea on grape and their effects on alcoholic fermentation. Front Microbiol 7:1249. https://doi.org/10.3389/fmicb .2016 .01249

Li G et al (2016) Stress tolerance and biocontrol performance of the yeast antagonist, Candida diversa, change with morphology transition. Environ Sci Pollut Res Int 23:2962-2967. https://doi. org/10.1007/s11356-015-5769-8

Liu HM, Guo JH, Liu P, Cheng YJ, Wang BQ, Long CA, Deng BX (2010) Inhibitory activity of tea polyphenol and Candida ernobii against Diplodia natalensis infections. J Appl Microbiol 108:1066-1072. https://doi.org/10.1111/j.1365-2672.2009.04511 . $\mathrm{x}$

Liu T et al (2012) Chitin-induced dimerization activates a plant immune receptor. Science 336:1160-1164. https://doi.org/10.1126/scien ce. 1218867

Liu X et al (2014) Host-induced bacterial cell wall decomposition mediates pattern-triggered immunity in Arabidopsis. Elife. https ://doi.org/10.7554/eLife.01990

Liu GL, Chi Z, Wang GY, Wang ZP, Li Y, Chi ZM (2015) Yeast killer toxins, molecular mechanisms of their action and their applications. Crit Rev Biotechnol 35:222-234. https://doi. org/10.3109/07388551.2013.833582

Liu P, Chen K, Li G, Yang X, Long CA (2016) Comparative transcriptional profiling of orange fruit in response to the biocontrol yeast Kloeckera apiculata and its active compounds. BMC Genom 17:17. https://doi.org/10.1186/s12864-015-2333-3

Liu J, Li G, Sui Y (2017) Optimization of culture medium enhances viable biomass production and biocontrol efficacy of the antagonistic yeast, Candida diversa. Front Microbiol. https://doi. org/10.3389/fmicb.2017.02021

Lohse MB, Gulati M, Johnson AD, Nobile CJ (2018) Development and regulation of single- and multi-species Candida albicans biofilms. Nat Rev Microbiol 16:19-31. https://doi.org/10.1038/ nrmicro.2017.107

Lopes FAC et al (2012) Biochemical and metabolic profiles of Trichoderma strains isolated from common bean crops in the Brazilian Cerrado, and potential antagonism against Sclerotinia sclerotiorum. Fungal Biol 116:815-824. https://doi.org/10.1016/j.funbi o.2012.04.015

Lopes MR, Klein MN, Ferraz LP, da Silva AC, Kupper KC (2015) Saccharomyces cerevisiae: a novel and efficient biological control agent for Colletotrichum acutatum during pre-harvest. Microbiol Res 175:93-99. https://doi.org/10.1016/j.micres.2015.04.003

Lowes KF, Shearman CA, Payne J, MacKenzie D, Archer DB, Merry RJ, Gasson MJ (2000) Prevention of yeast spoilage in feed and food by the yeast mycocin HMK. Appl Environ Microbiol 66:1066-1076

Lu L et al (2013) Preharvest application of antagonistic yeast Rhodosporidium paludigenum induced resistance against postharvest diseases in mandarin orange. Biol Control 67:130-136. https:// doi.org/10.1016/j.biocontrol.2013.07.016

Lu L, Xu S, Zeng L, Zheng X, Yu T (2014) Rhodosporidium paludigenum induced resistance in Ponkan mandarin against Penicillium digitatum requires ethylene-dependent signaling pathway. Postharvest Biol Technol 97:93-101. https://doi.org/10.1016/j. postharvbio.2014.06.007

Luksa J, Podoliankaite M, Vepstaite I, Strazdaite-Zieliene Z, Urbonavicius J, Serviene E (2015) Yeast beta-1,6-glucan is a primary target for the Saccharomyces cerevisiae K2 toxin. Eukaryot Cell 14:406-414. https://doi.org/10.1128/EC.00287-14

Lutz MC, Lopes CA, Rodriguez ME, Sosa MC, Sangorrin MP (2013) Efficacy and putative mode of action of native and commercial antagonistic yeasts against postharvest pathogens of pear. Int J Food Microbiol 164:166-172. https://doi.org/10.1016/j.ijfoo dmicro.2013.04.005

Macarisin D, Droby S, Bauchan G, Wisniewski M (2010) Superoxide anion and hydrogen peroxide in the yeast antagonist-fruit interaction: a new role for reactive oxygen species in postharvest biocontrol? Postharvest Biol Technol 58:194-202. https://doi. org/10.1016/j.postharvbio.2010.07.008

Mannazzu I et al (2019) Yeast killer toxins: from ecological significance to application. Crit Rev Biotechnol 39:603-617. https:// doi.org/10.1080/07388551.2019.1601679

Manuel J, Selin C, Fernando WG, de Kievit T (2012) Stringent response mutants of Pseudomonas chlororaphis PA23 exhibit enhanced antifungal activity against Sclerotinia sclerotiorum in vitro. Microbiology 158:207-216. https://doi.org/10.1099/ mic.0.053082-0

Marchand G, Clement-Mathieu G, Neveu B, Belanger RR (2007) Enhancing biological control efficacy of yeasts to control fungal diseases through biotechnology. In: Punja ZK, De Boer SH, Sanfaçon H (eds) Biotechnology and plant disease management. CAB International, Wallingford, pp 518-531. https://doi. org/10.1079/9781845932886.0518 
Marquina D, Barroso J, Santos A, Peinado JM (2001) Production and characteristics of Debaryomyces hansenii killer toxin. Microbiol Res 156:387-391. https://doi.org/10.1078/0944-5013-00117

Marquina D, Santos A, Peinado JM (2002) Biology of killer yeasts. Int Microbiol 5:65-71. https://doi.org/10.1007/s10123-002-0066-z

Maselko M, Heinsch SC, Chacon JM, Harcombe WR, Smanski MJ (2017) Engineering species-like barriers to sexual reproduction. Nat Commun 8:883. https://doi.org/10.1038/s41467-017-01007 $-3$

Maserti B, Podda A, Giorgetti L, Del Carratore R, Chevret D, Migheli Q (2015) Proteome changes during yeast-like and pseudohyphal growth in the biofilm-forming yeast Pichia fermentans. Amino Acids 47:1091-1106. https://doi.org/10.1007/s0072 6-015-1933-1

Masoud W, Poll L, Jakobsen M (2005) Influence of volatile compounds produced by yeasts predominant during processing of Coffea arabica in East Africa on growth and ochratoxin A (OTA) production by Aspergillus ochraceus. Yeast 22:1133-1142. https://doi. org/10.1002/yea.1304

Mayer FL, Wilson D, Hube B (2013) Candida albicans pathogenicity mechanisms. Virulence 4:119-128. https://doi.org/10.4161/ viru. 22913

Mbili NC (2012) Evaluation of integrated control of postharvest grey mould and blue mould of pome fruit using yeast, potassium silicate and hot water treatments. University of KwaZulu-Natal

McCormack P, Wildman HG, Jeffries P (1995) The influence of moisture on the suppression of Pseudomonas syringae by Aureobasidium pullulans on an artificial leaf surface. FEMS Microbiol Ecol 16:159-165. https://doi.org/10.1016/0168-6496(95)92762-Z

McLaughlin RJ, Wilson CL, Droby S, Benarie R, Chalutz E (1992) Biological control of postharvest diseases of grape, peach, and apple with the yeasts Kloeckera apiculata and Candida guilliermondii. Plant Dis 76:470-473

Miceli MH, Diaz JA, Lee SA (2011) Emerging opportunistic yeast infections. Lancet Infect Dis 11:142-151. https://doi. org/10.1016/S1473-3099(10)70218-8

Mimee B, Labbe C, Pelletier R, Belanger RR (2005) Antifungal activity of flocculosin, a novel glycolipid isolated from Pseudozyma flocculosa. Antimicrob Agents Chemother 49:1597-1599. https ://doi.org/10.1128/AAC.49.4.1597-1599.2005

Mimee B, Labbe C, Belanger RR (2009) Catabolism of flocculosin, an antimicrobial metabolite produced by Pseudozyma flocculosa. Glycobiology 19:995-1001. https://doi.org/10.1093/glyco b/cwp078

Molinu MG, Pani G, Venditti T, Dore A, Ladu G, D'Hallewin G (2011) Sequential application of $\mathrm{NaHCO}_{3}, \mathrm{CaCl}_{2}$ and Candida oleophila (isolate 13L) affects significantly Penicillum expansum growth and the infection degree in apples. Commun Agric Appl Biol Sci 76:743-750

Morales H, Sanchis V, Usall J, Ramos AJ, Marin S (2008) Effect of biocontrol agents Candida sake and Pantoea agglomerans on Penicillium expansum growth and patulin accumulation in apples. Int J Food Microbiol 122:61-67. https://doi.org/10.1016/j.ijfoo dmicro.2007.11.056

Morath SU, Hung R, Bennett JW (2012) Fungal volatile organic compounds: a review with emphasis on their biotechnological potential. Fungal Biol Rev 26:73-83. https://doi.org/10.1016/j. fbr.2012.07.001

Moriguchi K, Yamamoto S, Tanaka K, Kurata N, Suzuki K (2013) Trans-kingdom horizontal DNA transfer from bacteria to yeast is highly plastic due to natural polymorphisms in auxiliary nonessential recipient genes. PLoS ONE 8:e74590. https://doi. org/10.1371/journal.pone.0074590

Nagpure A, Choudhary B, Gupta RK (2014) Chitinases: in agriculture and human healthcare. Crit Rev Biotechnol 34:215-232. https:// doi.org/10.3109/07388551.2013.790874
Nigro F, Finetti Sialer MM, Gallitelli D (1999) Transformation of Metschnikowia pulcherrima 320, biocontrol agent of storage rot, with the green fluorescent protein gene. J Plant Pathol 81:205-208

Nunes C, Usall J, Teixido N, Abadias M, Viñas I (2002a) Improved control of postharvest decay of pears by the combination of Candida sake (CPA-1) and ammonium molybdate. Phytopathology 92:281-287. https://doi.org/10.1094/Phyto.2002.92.3.281

Nunes C, Usall J, Teixido N, Viñas I (2002b) Improvement of Candida sake biocontrol activity against post-harvest decay by the addition of ammonium molybdate. J Appl Microbiol 92:927-935

Oporto CI, Villarroel CA, Tapia SM, Garcia V, Cubillos FA (2019) Distinct transcriptional changes in response to patulin underlie toxin biosorption differences in Saccharomyces cerevisiae. Toxins (Basel). https://doi.org/10.3390/toxins 11070400

Opulente DA et al (2019) Pathogenic budding yeasts isolated outside of clinical settings. FEMS Yeast Res. https://doi.org/10.1093/ femsyr/foz032

Oro L, Feliziani E, Ciani M, Romanazzi G, Comitini F (2017) Volatile organic compounds from Wickerhamomyces anomalus, Metschnikowia pulcherrima and Saccharomyces cerevisiae inhibit growth of decay causing fungi and control postharvest diseases of strawberries. Int J Food Microbiol 265:18-22. https ://doi.org/10.1016/j.ijfoodmicro.2017.10.027

Ortu G, Demontis MA, Budroni M, Goyard S, d'Enfert C, Migheli Q (2005) Study of biofilm formation in Candida albicans may help understanding the biocontrol capability of a flor strain of Saccharomyces cerevisiae against the phytopathogenic fungus Penicillium expansum. J Plant Pathol 87:300

Pandin C, Le Coq D, Canette A, Aymerich S, Briandet R (2017) Should the biofilm mode of life be taken into consideration for microbial biocontrol agents? Microb Biotechnol 10:719-734. https://doi. org/10.1111/1751-7915.12693

Papanikolaou S, Aggelis G (2011) Lipids of oleaginous yeasts. Part I: biochemistry of single cell oil production. Eur J Lipid Sci Technol 113:1031-1051. https://doi.org/10.1002/ejlt.201100014

Papon N et al (2013) Candida guilliermondii: biotechnological applications, perspectives for biological control, emerging clinical importance and recent advances in genetics. Curr Genet 59:7390. https://doi.org/10.1007/s00294-013-0391-0

Parafati L, Vitale A, Restuccia C, Cirvilleri G (2015) Biocontrol ability and action mechanism of food-isolated yeast strains against Botrytis cinerea causing post-harvest bunch rot of table grape. Food Microbiol 47:85-92. https://doi.org/10.1016/j.fm.2014.11.013

Parafati L, Cirvilleri G, Restuccia C, Wisniewski M (2017a) Potential role of exoglucanase genes (WaEXG1 and WaEXG2) in the biocontrol activity of Wickerhamomyces anomalus. Microb Ecol 73:876-884. https://doi.org/10.1007/s00248-016-0887-5

Parafati L, Vitale A, Restuccia C, Cirvilleri G (2017b) Performance evaluation of volatile organic compounds by antagonistic yeasts immobilized on hydrogel spheres against gray, green and blue postharvest decays. Food Microbiol 63:191-198. https://doi. org/10.1016/j.fm.2016.11.021

Park M, Do E, Jung WH (2013) Lipolytic enzymes involved in the virulence of human pathogenic fungi. Mycobiology 41:67-72. https://doi.org/10.5941/MYCO.2013.41.2.67

Perez MF et al (2016) Native killer yeasts as biocontrol agents of postharvest fungal diseases in lemons. PLoS ONE 11:e0165590. https://doi.org/10.1371/journal.pone.0165590

Peter J et al (2018) Genome evolution across 1,011 Saccharomyces cerevisiae isolates. Nature 556:339-344. https://doi.org/10.1038/ s41586-018-0030-5

Piano S, Neyrotti V, Migheli Q, Gullino ML (1997) Biocontrol capability of Metschnikowia pulcherrima against Botrytis postharvest rot of apple. Postharvest Biol Technol 11:131-140. https://doi. org/10.1016/S0925-5214(97)00022-7 
Pieterse CM, Zamioudis C, Berendsen RL, Weller DM, Van Wees SC, Bakker PA (2014) Induced systemic resistance by beneficial microbes. Annu Rev Phytopathol 52:347-375. https://doi. org/10.1146/annurev-phyto-082712-102340

Pimenta RS, Silva FL, Silva JF, Morais PB, Braga DT, Rosa CA, Correa A Jr (2008) Biological control of Penicillium italicum, $P$. digitatum and $P$. expansum by the predacious yeast Saccharomycopsis schoenii on oranges. Braz J Microbiol 39:85-90. https ://doi.org/10.1590/S1517-838220080001000020

Piombo E et al (2018) Genome sequence, assembly and characterization of two Metschnikowia fructicola strains used as biocontrol agents of postharvest diseases. Front Microbiol 9:593. https:// doi.org/10.3389/fmicb.2018.00593

Pizzolitto RP, Armando MR, Combina M, Cavaglieri LR, Dalcero AM, Salvano MA (2012) Evaluation of Saccharomyces cerevisiae strains as probiotic agent with aflatoxin $\mathrm{B}(1)$ adsorption ability for use in poultry feedstuffs. J Environ Sci Health B 47:933-941. https://doi.org/10.1080/03601234.2012.706558

Pozo MI, Lachance MA, Herrera CM (2012) Nectar yeasts of two southern Spanish plants: the roles of immigration and physiological traits in community assembly. FEMS Microbiol Ecol 80:281-293. https://doi.org/10.1111/j.1574-6941.2011.01286.x

Prado G et al (2011) Reduction of aflatoxin B1 in stored peanuts (Arachis hypogaea L.) using Saccharomyces cerevisiae. J Food Protect 74:1003-1006. https://doi.org/10.4315/0362-028X. JFP-10-380

Prasongsuk S, Lotrakul P, Ali I, Bankeeree W, Punnapayak H (2018) The current status of Aureobasidium pullulans in biotechnology. Folia Microbiol (Praha) 63:129-140. https://doi.org/10.1007/ s12223-017-0561-4

Pretscher J et al (2018) Yeasts from different habitats and their potential as biocontrol agents. Fermentation 4:31. https://doi.org/10.3390/ fermentation4020031

Price NP, Manitchotpisit P, Vermillion KE, Bowman MJ, Leathers TD (2013) Structural characterization of novel extracellular liamocins (mannitol oils) produced by Aureobasidium pullulans strain NRRL 50380. Carbohydr Res 370:24-32. https://doi. org/10.1016/j.carres.2013.01.014

Price NP, Bischoff KM, Leathers TD, Cosse AA, Manitchotpisit P (2017) Polyols, not sugars, determine the structural diversity of anti-streptococcal liamocins produced by Aureobasidium pullulans strain NRRL 50380. J Antibiot (Tokyo) 70:136-141. https ://doi.org/10.1038/ja.2016.92

Pu L, Jingfan F, Kai C, Chao-an L, Yunjiang C (2014) Phenylethanol promotes adhesion and biofilm formation of the antagonistic yeast Kloeckera apiculata for the control of blue mold on citrus. FEMS Yeast Res 14:536-546. https://doi. org/10.1111/1567-1364.12139

Punja ZK, Utkhede RS (2003) Using fungi and yeasts to manage vegetable crop diseases. Trends Biotechnol 21:400-407. https://doi. org/10.1016/S0167-7799(03)00193-8

Querol A, Fleet GH (eds) (2006) Yeasts in food and beverages. The Yeast Handbook, vol 2. Springer, Heidelberg

Ramirez M, Velazquez R, Maqueda M, Lopez-Pineiro A, Ribas JC (2015) A new wine Torulaspora delbrueckii killer strain with broad antifungal activity and its toxin-encoding double-stranded RNA virus. Front Microbiol 6:983. https://doi.org/10.3389/fmicb .2015 .00983

Ren X, Kong Q, Wang H, Yu T, Tang YJ, Zhou WW, Zheng X (2012) Control of apple blue mold by Pichia pastoris recombinant strains expressing cecropin A. Bioprocess Biosyst Eng 35:761767. https://doi.org/10.1007/s00449-011-0656-2

Reynolds TB, Fink GR (2001) Bakers' yeast, a model for fungal biofilm formation. Science 291:878-881. https://doi.org/10.1126/scien ce.291.5505.878
Richards TA, Leonard G, Soanes D, Talbot N (2011) Gene transfer into the fungi. Fungal Biol Rev 25:98-110. https://doi.org/10.1016/j. fbr.2011.04.003

Robert V, Cardinali G, Casadevall A (2015) Distribution and impact of yeast thermal tolerance permissive for mammalian infection. BMC Biol 13:18. https://doi.org/10.1186/s12915-015-0127-3

Rodriguez-Cousino N, Maqueda M, Ambrona J, Zamora E, Esteban R, Ramirez M (2011) A new wine Saccharomyces cerevisiae killer toxin (Klus), encoded by a double-stranded rna virus, with broad antifungal activity is evolutionarily related to a chromosomal host gene. Appl Environ Microbiol 77:1822-1832. https://doi. org/10.1128/AEM.02501-10

Rossouw D, Meiring SP, Bauer FF (2018) Modifying Saccharomyces cerevisiae adhesion properties regulates yeast ecosystem dynamics. mSphere. https://doi.org/10.1128/msphere.00383-18

Saligkarias ID, Gravanis FT, Epton HAS (2002) Biological control of Botrytis cinerea on tomato plants by the use of epiphytic yeasts Candida guilliermondii strains 101 and US 7 and Candida oleophila strain I-182: I. in vivo studies. Biol Control 25:143150. https://doi.org/10.1016/S1049-9644(02)00051-8

Sánchez-Pérez LdC, Barranco-Florido JE, Rodríguez-Navarro S, Cervantes-Mayagoitia JF, Ramos-Lopez MÁ (2014) Enzymes of entomopathogenic fungi, advances and insights. Adv Enzyme Res 2:65-76. https://doi.org/10.4236/aer.2014.22007

Sanna ML, Zara S, Zara G, Migheli Q, Budroni M, Mannazzu I (2012) Pichia fermentans dimorphic changes depend on the nitrogen source. Fungal Biol 116:769-777. https://doi.org/10.1016/j.funbi o.2012.04.008

Sanna ML, Zara G, Zara S, Migheli Q, Budroni M, Mannazzu I (2013) A putative phospholipase $\mathrm{C}$ is involved in Pichia fermentans dimorphic transition. Biochim Biophys Acta 1840:344-349. https://doi.org/10.1016/j.bbagen.2013.09.030

Santos A, Marquina D (2004a) Ion channel activity by Pichia membranifaciens killer toxin. Yeast 21:151-162. https://doi. org/10.1002/yea.1069

Santos A, Marquina D (2004b) Killer toxin of Pichia membranifaciens and its possible use as a biocontrol agent against grey mould disease of grapevine. Microbiology 150:2527-2534. https://doi. org/10.1099/mic.0.27071-0

Santos A, Marquina D, Barroso J, Peinado JM (2002) (1 $\rightarrow 6$ )-BetaD-glucan as the cell wall binding site for Debaryomyces hansenii killer toxin. Lett Appl Microbiol 34:95-99. https://doi. org/10.1046/j.1472-765x.2002.01053.x

Santos A, San Mauro M, Bravo E, Marquina D (2009) PMKT2, a new killer toxin from Pichia membranifaciens, and its promising biotechnological properties for control of the spoilage yeast Brettanomyces bruxellensis. Microbiology 155:624-634. https://doi. org/10.1099/mic.0.023663-0

Saravanakumar D, Clavorella A, Spadaro D, Garibaldi A, Gullino ML (2008) Metschnikowia pulcherrima strain MACH1 outcompetes Botrytis cinerea, Alternaria alternata and Penicillium expansum in apples through iron depletion. Postharvest Biol Technol 49:121-128. https://doi.org/10.1016/j.postharvbio.2007.11.006

Saravanakumar D, Spadaro D, Garibaldi A, Gullino ML (2009) Detection of enzymatic activity and partial sequence of a chitinase gene in Metschnikowia pulcherrima strain MACH1 used as postharvest biocontrol agent. Eur J Plant Pathol 123:183-193. https ://doi.org/10.1007/s10658-008-9355-5

Schaible UE, Kaufmann SH (2005) A nutritive view on the hostpathogen interplay. Trends Microbiol 13:373-380. https://doi. org/10.1016/j.tim.2005.06.009

Scherm B, Ortu G, Muzzu A, Budroni M, Arras G, Migheli Q (2003) Biocontrol activity of antagonistic yeasts against Penicillium expansum on apple. J Plant Pathol 85:205-213 
Schmitt MJ, Breinig F (2002) The viral killer system in yeast: from molecular biology to application. FEMS Microbiol Rev 26:257-276

Schmitt MJ, Breinig F (2006) Yeast viral killer toxins: lethality and self-protection. Nat Rev Microbiol 4:212-221. https://doi. org/10.1038/nrmicro1347

Schmitt MJ, Schernikau G (1997) Construction of a cDNA-based K1/ K2/K28 triple killer strain of Saccharomyces cerevisiae. Food Technol Biotechnol 35:281-285

Segal E, Yehuda H, Droby S, Wisniewski M, Goldway M (2002) Cloning and analysis of CoEXG1, a secreted 1,3- $\beta$-glucanase of the yeast biocontrol agent Candida oleophila. Yeast 19:1171-1182. https://doi.org/10.1002/yea.910

Seibold A, Fried A, Kunz S, Moltmann E, Lange E, Jelkmann W (2004) Yeasts as antagonists against fireblight. EPPO Bull. https ://doi.org/10.1111/j.1365-2338.2004.00766.x

Shalaby ME-S, El-Nady MF (2008) Application of Saccharomyces cerevisiae as a biocontrol agent against Fusarium infection of sugar beet plants. Acta Biol Szegediensis 52:271-275

Sipiczki M (2006) Metschnikowia strains isolated from botrytized grapes antagonize fungal and bacterial growth by iron depletion. Appl Environ Microb 72:6716-6724. https://doi.org/10.1128/ Aem.01275-06

Slavikova E, Vadkertiova R, Vranova D (2007) Yeasts colonizing the leaf surfaces. J Basic Microbiol 47:344-350. https://doi. org/10.1002/jobm.200710310

Sommer B, Overy DP, Haltli B, Kerr RG (2016) Secreted lipases from Malassezia globosa: recombinant expression and determination of their substrate specificities. Microbiology 162:1069-1079. https://doi.org/10.1099/mic.0.000299

Spadaro D, Droby S (2016) Development of biocontrol products for postharvest diseases of fruit: the importance of elucidating the mechanisms of action of yeast antagonists. Trends Food Sci Technol 47:39-49. https://doi.org/10.1016/j.tifs.2015.11.003

Spadaro D, Gullino ML (2005) Improving the efficacy of biocontrol agents against soilborne pathogens. Crop Prot 24:601-613. https ://doi.org/10.1016/j.cropro.2004.11.003

Spadaro D, Ciavorella A, Dianpeng Z, Garibaldi A, Gullino ML (2010a) Effect of culture media and $\mathrm{pH}$ on the biomass production and biocontrol efficacy of a Metschnikowia pulcherrima strain to be used as a biofungicide for postharvest disease control. Can J Microbiol 56:128-137. https://doi.org/10.1139/ w09-117

Spadaro D, Ciavorella AA, Lopez-Reyes JG, Garibaldi A, Gullino ML (2010b) Effect of culture age, protectants, and initial cell concentration on viability of freeze-dried cells of Metschnikowia pulcherrima. Can J Microbiol 56:809-815. https://doi.org/10.1139/w10-068

Sun C, Fu D, Lu H, Zhang J, Zheng X, Yu T (2018) Autoclaved yeast enhances the resistance against Penicillium expansum in postharvest pear fruit and its possible mechanisms of action. Biol Control 119:51-58. https://doi.org/10.1016/j.biocontrol .2018 .01 .010

Suzuki C, Nikkuni S (1994) The primary and subunit structure of a novel type killer toxin produced by a halotolerant yeast, Pichia farinosa. J Biol Chem 269:3041-3046

Szczęsna-Antczak M, Kamińska J, Florczak T, Turkiewicz M (2014) Cold-active yeast lipases: recent issues and future prospects. In: Buzzini P, Margesin R (eds) Cold-adapted yeasts: biodiversity, adaptation strategies and biotechnological significance. Springer, Berlin, pp 353-375. https://doi.org/10.1007/978-3-642-39681 $-6 \_16$

Takesako K et al (1991) Aureobasidins, new antifungal antibiotics. Taxonomy, fermentation, isolation, and properties. J Antibiot (Tokyo) 44:919-924. https://doi.org/10.7164/antibiotics.44.919
Teichmann B, Labbe C, Lefebvre F, Bolker M, Linne U, Belanger RR (2011) Identification of a biosynthesis gene cluster for flocculosin a cellobiose lipid produced by the biocontrol agent Pseudozyma flocculosa. Mol Microbiol 79:1483-1495. https://doi.org /10.1111/j.1365-2958.2010.07533.x

Tian SP, Qin GZ, Xu Y, Wang YS (2004) Application of antagonistic yeasts under field conditions and their biocontrol ability against postharvest diseases of sweet cherry. Acta Bot Sin 46:1324-1330

Tilocca B, Balmas V, Hassan ZU, Jaoua S, Migheli Q (2019) A proteomic investigation of Aspergillus carbonarius exposed to yeast volatilome or to its major component 2-phenylethanol reveals major shifts in fungal metabolism. Int J Food Microbiol 306:108265. https://doi.org/10.1016/j.ijfoodmicro.2019.108265

Torres R, Usall J, Teixido N, Abadias M, Viñas I (2003) Liquid formulation of the biocontrol agent Candida sake by modifying water activity or adding protectants. J Appl Microbiol 94:330-339. https://doi.org/10.1046/j.1365-2672.2003.01843.x

Torres R, Teixido N, Viñas I, Mari M, Casalini L, Giraud M, Usall J (2006) Efficacy of Candida sake CPA-1 formulation for controlling Penicillium expansum decay on pome fruit from different Mediterranean regions. J Food Prot 69:2703-2711

Tsai PW, Yang CY, Chang HT, Lan CY (2011) Human antimicrobial peptide LL-37 inhibits adhesion of Candida albicans by interacting with yeast cell-wall carbohydrates. PLoS ONE 6:e17755. https://doi.org/10.1371/journal.pone.0017755

Turkel S, Korukluoglu M, Yavuz M (2014) Biocontrol activity of the local strain of Metschnikowia pulcherrima on different postharvest pathogens. Biotechnol Res Int. https://doi. org/10.1155/2014/397167

Urquhart EJ, Punja ZK (2002) Hydrolytic enzymes and antifungal compounds produced by Tilletiopsis species, phyllosphere yeasts that are antagonists of powdery mildew fungi. Can J Microbiol 48:219-229. https://doi.org/10.1139/w02-008

Usall J, Teixido N, Fons E, Viñas I (2000) Biological control of blue mould on apple by a strain of Candida sake under several controlled atmosphere conditions. Int J Food Microbiol 58:83-92. https://doi.org/10.1016/S0168-1605(00)00285-3

Usall J, Torres R, Teixidó N (2016) Biological control of postharvest diseases on fruit: a suitable alternative? Curr Opin Food Sci 11:51-55. https://doi.org/10.1016/j.cofs.2016.09.002

Vadkertiova R, Molnarova J, Vranova D, Slavikova E (2012) Yeasts and yeast-like organisms associated with fruits and blossoms of different fruit trees. Can J Microbiol 58:1344-1352. https://doi. org/10.1139/cjm-2012-0468

Vepstaite-Monstavice I et al (2018) Saccharomyces paradoxus K66 killer system evidences expanded assortment of helper and satellite viruses. Viruses. https://doi.org/10.3390/v10100564

Verstrepen KJ, Klis FM (2006) Flocculation, adhesion and biofilm formation in yeasts. Mol Microbiol 60:5-15. https://doi.org/10.111 1/j.1365-2958.2006.05072.x

Vial L, Groleau MC, Dekimpe V, Deziel E (2007) Burkholderia diversity and versatility: an inventory of the extracellular products. $\mathrm{J}$ Microbiol Biotechnol 17:1407-1429

Wachowska U, Głowacka K, Mikołajczyk W, Kucharska K (2016) Biofilm of Aureobasidium pullulans var. pullulans on winter wheat kernels and its effect on other microorganisms. Microbiology 85:523-530. https://doi.org/10.1134/S0026261716050192

Wang X, Chi Z, Yue L, Li J (2007) Purification and characterization of killer toxin from a marine yeast Pichia anomala YF07b against the pathogenic yeast in crab. Curr Microbiol 55:396-3401. https ://doi.org/10.1007/s00284-007-9010-y

Wang W, Chi Z, Liu G, Buzdar MA, Chi Z, Gu Q (2009a) Chemical and biological characterization of siderophore produced by the marine-derived Aureobasidium pullulans HN6.2 and its antibacterial activity. Biometals 22:965-972. https://doi.org/10.1007/ s10534-009-9248-x 
Wang WL, Chi ZM, Chi Z, Li J, Wang XH (2009b) Siderophore production by the marine-derived Aureobasidium pullulans and its antimicrobial activity. Bioresour Technol 100:2639-2641. https ://doi.org/10.1016/j.biortech.2008.12.010

Wang XX, Chi Z, Peng Y, Wang XH, Ru SG, Chi ZM (2012a) Purification, characterization and gene cloning of the killer toxin produced by the marine-derived yeast Williopsis saturnus WC91-2. Microbiol Res 167:558-563. https://doi.org/10.1016/j.micre s.2011.12.001

Wang Y, Wei A, Li H (2012b) Using Candida oleophila as a biocontriol agens to prevent foodborne Escherichia coli O157 EHEC infections. Springerplus 1:82. https://doi.org/10.1186/2193-1801-1-82

Weiler F, Schmitt MJ (2003) Zygocin, a secreted antifungal toxin of the yeast Zygosaccharomyces bailii, and its effect on sensitive fungal cells. FEMS Yeast Res 3:69-76. https://doi.org/10.1016/ s1567-1356(02)00126-5

Weiss A, Mögel G (2006) Kunz S Development of "Boni-Protect"- a yeast preparation for use in the control of post-harvest diseases of apples. In: Boos M (ed) 12th International conference on cultivation technique and phytopathologtical problems in organic fruit-growing. Weinsberg, Germany, pp 113-117

Weiss A, Weisshaupt S, Krawiec P, Kunz S (2014) Use of Aureobasidium pullulans for resistance management in chemical control of Botrytis cinerea in berries. Acta Hortic 1017:237-242. https ://doi.org/10.17660/ActaHortic.2014.1017.30

Wilson C, El-Ghaouth A (2002) Biological coating with a protective and curative effect for the control of postharvest decay. USA Patent US 6,423,310 B1, 23 July 2002

Wisniewski M, Droby S (2012) Biopreservation of food and feed by postharvest biocontrol with microorganisms. In: Sundh I, Wilcks A, Goettel MS (eds) Beneficial microorganisms in agriculture, food and the environment. CABI International, Oxfordshire, pp 57-66

Wisniewski M, Biles C, Droby S, R, Wilson C, Chalutz E (1991) Mode of action of the postharvest biocontrol yeast, Pichia guilliermondii.1. Characterization of attachment to Botrytis cinerea. Physiol Mol Plant 39:245-258. https://doi.org/10.1016/08855765(91)90033-e

Wisniewski M, Droby S, Chalutz E, Eilam Y (1995) Effects of $\mathrm{Ca}^{2+}$ and $\mathrm{Mg}^{2+}$ on Botrytis cinerea and Penicillium expansum in vitro and on the biocontrol activity of Candida oleophila. Plant Pathol 44:1016-1024. https://doi.org/10.1111/j.1365-3059.1995.tb026 60.x

Wisniewski M et al (2003) Characterization of a defensin in bark and fruit tissues of peach and antimicrobial activity of a recombinant defensin in the yeast, Pichia pastoris. Physiol Plant 119:563-572. https://doi.org/10.1046/j.1399-3054.2003.00204.x

Wisniewski M, Wilson C, Droby S, Chalutz E, El Ghaouth A, Stevens C (2007) Postharvest biocontrol: new concepts and applications. https://doi.org/10.1079/9781845932657.0262

Xu H, Nobile CJ, Dongari-Bagtzoglou A (2013) Glucanase induces filamentation of the fungal pathogen Candida albicans. PLoS ONE 8:e63736. https://doi.org/10.1371/journal.pone.0063736

Yan F, Xu S, Chen Y, Zheng X (2014) Effect of rhamnolipids on Rhodotorula glutinis biocontrol of Alternaria alternata infection in cherry tomato fruit. Postharvest Biol Technol 97:32-35. https:// doi.org/10.1016/j.postharvbio.2014.05.017
Yehuda H, Droby S, Wisniewski M, Goldway M (2001) A transformation system for the biocontrol yeast, Candida oleophila, based on hygromycin B resistance. Curr Genet 40:282-287. https://doi. org/10.1007/s00294-001-0255-x

Yehuda H, Droby S, Bar-Shimon M, Wisniewski M, Goldway M (2003) The effect of under- and overexpressed CoEXG1-encoded exoglucanase secreted by Candida oleophila on the biocontrol of Penicillium digitatum. Yeast 20:771-780. https://doi. org/10.1002/yea.1006

Yu T, Zheng XD (2006) Salicylic acid enhances biocontrol efficacy of the antagonist Cryptococcus laurentii in apple fruit. J Plant Growth Regul 25:166-174. https://doi.org/10.1007/s0034 4-005-0077-Z

Yurkov AM (2018) Yeasts of the soil - obscure but precious. Yeast 35:369-378. https://doi.org/10.1002/yea.3310

Zain M, Awaad A, Razzak A, Maitland D, El-Sayed N, Sakhawy M (2009) Secondary metabolites of Aureobasidium pullulans isolated from egyptian soil and their biological activity. J Appl Sci Res 5:1582-1591

Zajc J, Gostincar C, Cernosa A, Gunde-Cimerman N (2019) Stresstolerant yeasts: opportunistic pathogenicity versus biocontrol potential. Genes (Basel) 10:42. https://doi.org/10.3390/genes 10010042

Zha D, Xu L, Zhang H, Yan Y (2014) Molecular identification of lipase LipA from Pseudomonas protegens Pf-5 and characterization of two whole-cell biocatalysts Pf-5 and Top10lipA. J Microbiol Biotechnol 24:619-628. https://doi.org/10.4014/jmb.1312.12005

Zhang HY, Zheng XD, Wang L, Li SS, Liu RF (2007a) Effect of yeast antagonist in combination with hot water dips on postharvest Rhizopus rot of strawberries. J Food Eng 78:281-287. https:// doi.org/10.1016/j.jfoodeng.2005.09.027

Zhang HY, Zheng XD, Yu T (2007b) Biological control of postharvest diseases of peach with Cryptococcus laurentii. Food Control 18:287-291. https://doi.org/10.1016/j.foodcont.2005.10.007

Zhang S, Schisler DA, Boehm MJ, Slininger PJ (2007c) Utilization of chemical inducers of resistance and Cryptococcus flavescens $\mathrm{OH}$ 182.9 to reduce Fusarium head blight under greenhouse conditions. Biol Control 42:308-315. https://doi.org/10.1016/j.bioco ntrol.2007.05.020

Zhang D, Spadaro D, Garibaldi A, Gullino ML (2011) Potential biocontrol activity of a strain of Pichia guilliermondii against grey mold of apples and its possible modes of action. Biol Control 57:193-201. https://doi.org/10.1016/j.biocontrol.2011.02.011

Zhang D, Spadaro D, Valente S, Garibaldi A, Gullino ML (2012) Cloning, characterization, expression and antifungal activity of an alkaline serine protease of Aureobasidium pullulans PL5 involved in the biological control of postharvest pathogens. Int J Food Microbiol 153:453-464. https://doi.org/10.1016/j.ijfoo dmicro.2011.12.016

Publisher's Note Springer Nature remains neutral with regard to jurisdictional claims in published maps and institutional affiliations. 